\title{
Third U.S. Geological Survey Wildland Fire-Science Workshop Denver, Colorado November 12-15, 2002
}

By Russell K. Livingston

Scientific Investigations Report 2004-5005 


\title{
U.S. Department of the Interior \\ Gale A. Norton, Secretary \\ U.S. Geological Survey \\ Charles G. Groat, Director
}

\section{U.S. Geological Survey, Reston, Virginia: 2004}

\author{
For sale by U.S. Geological Survey, Information Services \\ Box 25286, Denver Federal Center \\ Denver, CO 80225 \\ For more information about the USGS and its products: \\ Telephone: 1-888-ASK-USGS \\ World Wide Web: http://www.usgs.gov/
}

Any use of trade, product, or firm names in this publication is for descriptive purposes only and does not imply endorsement by the U.S. Government.

Suggested citation:

Livingston, Russell K., 2003, Third U.S. Geological Survey Wildland Fire-Science Workshop, Denver, Colorado, November 12-15, 2002: U.S. Geological Survey Scientific Investigations Report 2004-5005, 67 p. 


\section{Third U.S. Geological Survey Wildland Fire-Science Workshop Denver, Colorado November 12-15, 2002}

\section{Executive Summary}

The historically significant wildland fire events that occurred in the United States during 2000 and 2002, together with the associated recognition of the need for a different national policy of forest management, has led to an increased awareness of the need for cooperative effort among all Federal agencies in planning for and managing the risks and consequences of wildland fire. The expertise and capabilities of the U.S. Geological Survey (USGS) are significant resources in this regard, and the agency is becoming increasingly involved in fire-science activities in support of the various land-management agencies that are dealing directly with this issue.

The First USGS Wildland Fire Workshop was held in Sioux Falls, South Dakota, in 1997 and helped to establish the direction of USGS in sharing its expertise with the fire-management agencies. The Second USGS Wildland Fire Workshop was held in Los Alamos, New Mexico, in 2000 and brought together all the agencies involved in the management of wildland fires in order to determine their needs, to demonstrate USGS capabilities to meet those needs, and to establish methods for the USGS to distribute data and tools useful in fire management. It enhanced the relationships developed during the 1997 workshop and helped to define USGS' role in the fire-management community.

The Third USGS Wildland Fire-Science Workshop, held in Denver, Colorado, November 12-15, 2002, was an opportunity for exchange of information on recent progress in the area of fire science and to determine the gaps in fire-science research that could be addressed by the USGS. In addition to more than 90 USGS scientists engaged in fire-related research and managers of organizational units involved in some aspect of wildland fire activities, the workshop was attended by about 30 representatives of 11 other Federal agencies. There also were a number of attendees affiliated with several universities, private companies, and State and local agencies.

The 4-day meeting consisted of a pre-workshop field trip to the Hayman Fire area, several keynote presentations, five panel discussions, presentation and "breakout" discussion of four "white paper" topics, and a poster session with more than 30 presentations. 


\section{Third U.S. Geological Survey Wildland Fire-Science Workshop Denver, Colorado November 12-15, 2002}

\section{Preface}

\section{Historical Perspective}

In the past decade, fire-management policies have shifted from emphasizing suppression to embracing the reduction of long-term buildups of excessive fuel levels in our forests and rangelands. In 1995, the Departments of Agriculture and the Interior issued the Federal Wildland Fire Policy Statement identifying the critical role fire can play in the management of forest and rangeland watersheds. As a result of revised policy, Federal agencies have increased the acres treated to reduce fire risk (through "prescribed" fires and thinning techniques) from 500,000 acres in 1995 to more than 2.4 million acres in 2000 . The fire events that occurred during the summer and fall of 2000 reemphasized the need for cooperative effort among all Federal agencies in planning for and managing wildland fire risk. The number and size of fires throughout the Western United States provided further evidence that past land-use practices and vigorous fire-suppression and exclusion policies may have increased the potential for devastating effects of high fuel loads in drought-affected areas.

On August 8, 2000, President Clinton asked the Secretaries of the Interior and Agriculture to prepare a report that recommended how best to respond to that year's severe fires, reduce the effects of these wildland fires on rural communities, and ensure sufficient firefighting resources in the future. Their response to the President, the National Fire Plan, was published in September 2000 and led to a 10-year Comprehensive Strategy and a 10-year Implementation Plan. All of these three important policy documents focused on four goals:

1. Improve fire prevention and suppression

2. Reduce hazardous fuels

3. Restore fire-adapted ecosystems

4. Promote community assistance

As the year 2002 evolved into a fire season that began to look more and more like the devastating 2000 fire season, President Bush announced the Healthy Forest Initiative. Aimed at reducing the risk of catastrophic wildfires by restoring forest and rangeland health, this effort would implement core components of the National Fire Plan's 10-year Comprehensive Strategy and Implementation Plan and "fulfill the promise of the Northwest Forest Plan." The Northwest Forest Plan was adopted in 1994 and was intended to end court injunctions that brought timber production in the Pacific Northwest to a standstill by providing an adequate level of habitat protection for old growth forest species and a predictable timber supply for economic stability. Among the many features of the Healthy Forest Initiative was a request that Agriculture 
Secretary Veneman, Interior Secretary Norton, and Council on Environmental Quality Chairman Connaughton improve regulatory processes to ensure more timely decisions, greater efficiency, and better results in reducing the Nation's ever-growing risks of catastrophic wildfires.

\section{Year 2002 Wildland Fire Season}

According to the National Interagency Fire Center, a total of 6,937,584 acres burned nationwide during the 2002 fire season. This number represents the fourth greatest number of acres burned in the Nation in the last 50 years and only about 1,500,000 fewer acres than burned during the devastating 2000 fire season. The areas burned in Colorado, Arizona, and Oregon represented the greatest number of acres burned in the last century in those States. Like the 2000 fire season that preceded the workshop in Los Alamos, the 2002 fire season supported earlier conclusions and the growing recognition that past land-use practices, combined with the effects of fire exclusion, can result in heavy accumulations of dead vegetation, altered fuel arrangement, and changes in vegetation structure and composition. And like the 2000 fire season, the 2002 fire season also set the stage for an interesting and exciting USGS Wildland Fire-Science Workshop.

\section{Summary of Major Activities Since the Second Workshop on Fire Science}

The Second Workshop on Fire Science, which was held in Los Alamos, New Mexico, October 31November 3,2000, resulted in part from an increasing realization within the agency that the USGS had an important part to play relative to fire science. The national policy was changing, and increased focus was being placed on the management of the Nation's forests in order to reduce the potential for devastating fires such as those that occurred in 2000. Thus, that workshop was a watershed event for the USGS and resulted in programmatic and organizational changes that led to an expansion of its fire-related activities and involvement in the fire community. It was becoming increasingly clear that the USGS could contribute to the science needed by the management agencies. To illustrate this progress, the following is a summary of the major activities of the USGS during 2001-2002 as they relate to the four goals of the National Fire Plan:

- Expansion of mapping products, particularly burn severity, for use by the firefighting community

- Development of a 40-hour Basic Fire Training course, which was attended by 40 USGS personnel during the 2-year period. Of those attending the course, 18 have a "red card" that allows access to wildfire areas for early planning and collection of critical monitoring data

- Participation in studies by the Government Accounting Office relative to use of remote sensing in addressing wildland fire issues

- Initiation in February 2002 of the LandFire project, a collaboration between the USGS and the USDA Forest Service

- Refinement and expansion of GeoMAC (Geospatial Multi-Agency Coordination Group) to offer new capabilities

- Establishment of a USGS Web site for fire-science activities

- Collaboration with the USDA, Forest Service, and the National Weather Service on a "white paper" to document a plan for the establishment of rapid response, post-fire early warning networks for monitoring precipitation and stream stage 
- Participation in development of the "10-Year Comprehensive Strategy" and the companion "10-Year Strategy Implementation Plan"

- Increased participation of USGS scientists in the Joint Fire Science Program

- Publication and distribution of USGS Open-File Report 02-11 on the Second USGS Workshop on Fire Science that was held in Los Alamos, New Mexico, in November 2000

Other major activities during this period:

- As a result of the Hayman fire in Colorado, a program with the Federal Emergency Management Agency was developed to refine post-fire hydrologic and sedimenttransport conditions and map flood-prone areas

- An increased number of integrated science projects dealing with fire science

- Participation in the development of the Fire Science Research Council

- Development of a Memorandum of Understanding between the USGS and the Bureau of Land Management that provides for post-fire technical support relative to wildland fires

- Participation in the 2002 Western Governors Conference on the Environment

- Numerous presentations to other Federal agencies, congressional representatives, and attendees of fire-science conferences

- Fire Science selected as one of three topics for congressional briefings in 2002

- Increased post-fire monitoring activities supported by funding from Burned Area Emergency Response (BAER) teams and State and local cooperators

- USGS involvement in BAER training, including instruction of USGS scientists at the interagency ESR (Emergency Stabilization and Rehabilitation) and BAER Team Leader and Team Member training in Reno, Nevada, December 2002

- USGS involvement in numerous post-fire BAER team activities, including the Missionary Ridge and Coal Seam fires 


\section{Contents}

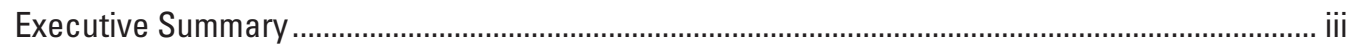

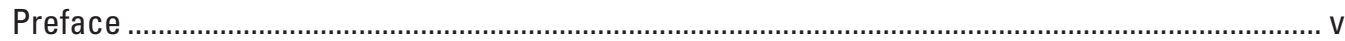

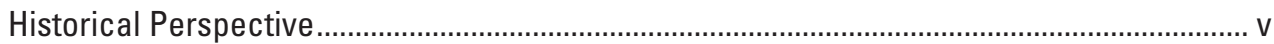

Year 2002 Wildland Fire Season ................................................................................................ vi

Summary of Major Activities Since the Second Wildland Fire Workshop................................ vi

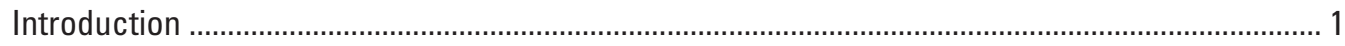

Summary of the Third Wildland Fire-Science Workshop................................................................ 1

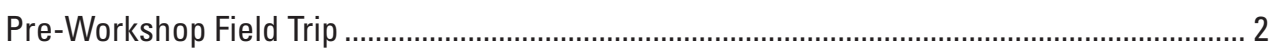

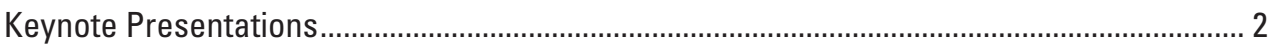

Panel Discussions ................................................................................................................. 3

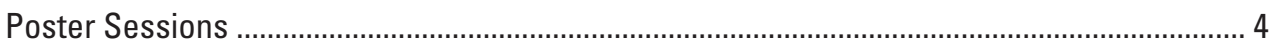

White Paper Presentations and Breakout Sessions .............................................................. 4

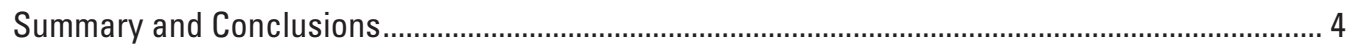

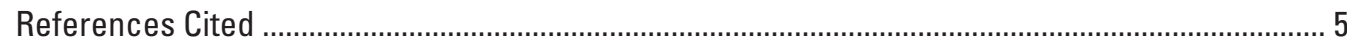

Appendix A-Agenda for Pre-Workshop Field Trip ................................................................

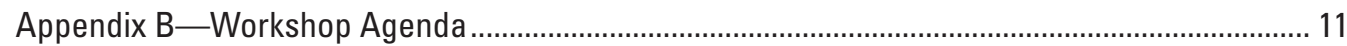

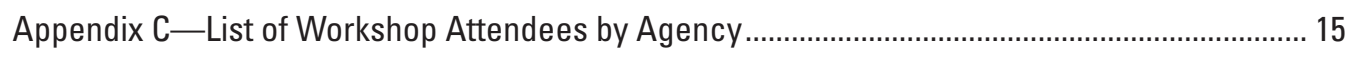

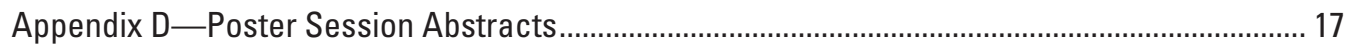

Appendix E-White Paper on Pre-Fire Risk Assessment and Fuels Mapping ............................... 49

Appendix F-White Paper on Post-Fire Effects, Including Physical and Biological ..................... 53

Appendix G-White Paper on Rehabilitation and Restoration ................................................. 57

Appendix H—White Paper on a USGS Fire Response Plan .......................................................... 63

\section{Tables}

1. Summary of activities of USGS scientists involved in the study of post-fire rehabilitation and restoration

2. Proposed rehabilitation and restoration actions to improve USGS fire science, internal collaboration, and external partnerships. 


\title{
Abbreviations and Acronyms
}

\author{
Federal Agencies and Organizations \\ ARS \\ Agricultural Research Service \\ BIA \\ Bureau of Indian Affairs \\ BLM \\ Bureau of Land Management \\ DOD \\ Department of Defense \\ DOI \\ Department of Interior \\ FEMA \\ Federal Emergency Management Agency \\ FWS \\ U.S. Fish and Wildlife Service \\ NIFC \\ National Interagency Fire Center \\ NPS \\ National Park Service \\ NRCS \\ Natural Resources Conservation Service \\ USBR \\ Department of the Interior, Bureau of Reclamation \\ USGS \\ Department of the Interior, U.S. Geological Survey \\ USGS-Biology USGS, Biological Resources Discipline \\ USGS-Geography \\ USGS, Geography Discipline (formerly the National Mapping \\ Division of USGS) \\ USGS-Geology \\ USGS, Geology Discipline \\ USGS-Water \\ USGS, Water Resources Discipline
}

\section{Other Acronyms and Initialisms}

AVHRR

AVIRIS

BAER

GIS

MODIS

RAWS

TNC
Advanced Very High Resolution Radiometer

Airborne Visible Infrared Imaging Spectrometer

Burned Area Emergency Rehabilitation

Geographical Information System

Moderate Resolution Imaging Spectroradiometer

Remote Automated Weather Station

The Nature Conservancy 


\title{
Third U.S. Geological Survey Wildland Fire-Science Workshop Denver, Colorado November 12-15, 2002
}

\author{
By Russell K. Livingston
}

\section{Introduction}

This report summarizes the Third USGS Wildland FireScience Workshop, which was held on November 12-15, 2002, at Denver, Colorado. The agenda for the pre-workshop field trip is given in Appendix A and the agenda for the workshop is given in Appendix B.

This workshop was planned to build on the accomplishments and recommendations of the USGS' first Wildland Fire Workshop held at the EROS Data Center in Sioux Falls, South Dakota, July 9-10, 1997 (Coloff, Findley, and Helz, 1998), and the Second Wildland Fire Workshop held in Los Alamos, New Mexico, October 31-November 3, 2000 (Coffelt and Livingston, 2002). Activities within the USGS in the area of fire science have increased substantially since that first workshop, and this third workshop was an additional step toward enhancing the visibility and effectiveness of the USGS fire-science activities.

The overall objective of the workshop was to provide an opportunity for exchange of information on recent progress in the area of fire science and to begin determining gaps in fire-science research that potentially could be addressed by the USGS. In pursuing that objective, the specific objectives of the workshop were to:

- Increase internal and external communication of USGS fire-science activities, particularly progress during the past 2 years

- Provide a forum for open discussion of new research directions

- Provide information on new technologies and tools of interest to scientists and land managers

- Develop and finalize a plan for USGS support of the National Fire Plan

- Further define the role of USGS relative to fire science and the National Fire Plan

- Provide an opportunity for exchange of information on research needs as the basis for future research and USGS support to other Federal agencies
This report describes workshop activities and contains a list of attendees, poster session abstracts, and white papers about four topics discussed at the workshop. The Universal Resource Locator (URL) for the fire-science Web site is provided in the "Summary and Conclusions" section.

\section{Summary of the Third Wildland Fire-Science Workshop}

The Central Region, Office of the Regional Director, hosted the workshop. In addition to more than 90 USGS scientists engaged in fire-related research and managers of organizational units involved in some aspect of wildland fire activities, the workshop was attended by about 30 representatives of the following agencies:

- Bureau of Land Management (BLM)

- Federal Emergency Management Agency (FEMA)

- Government Accounting Office (GAO)

- National Institute of Standards and Technology (NIST)

- National Interagency Fire Center (NIFC)

- National Park Service (NPS)

- USDA Cooperative Research

- USDA Forest Service

- U.S. Department of the Interior

- U.S. Environmental Protection Agency (USEPA)

- U.S. Fish and Wildlife Service (FWS)

There also were 13 attendees affiliated with several different universities, private companies, and State and local agencies. Appendix $\mathrm{C}$ is a listing of all attendees.

The 4-day meeting consisted of a pre-workshop field trip to the Hayman fire area, several keynote presentations, five panel discussions, presentation and "breakout" discussion of four "white paper" topics, and a poster session. 


\section{Pre-Workshop Field Trip}

Located only about 1 hour from Denver, the Hayman fire area was the site of the pre-workshop field trip, which was attended by about 35 of the workshop participants. Planned by the USGS Colorado District, the field trip included presentations by USGS scientists and several USGS cooperators who represented State and local agencies. The agenda for the field trip is presented in Appendix A.

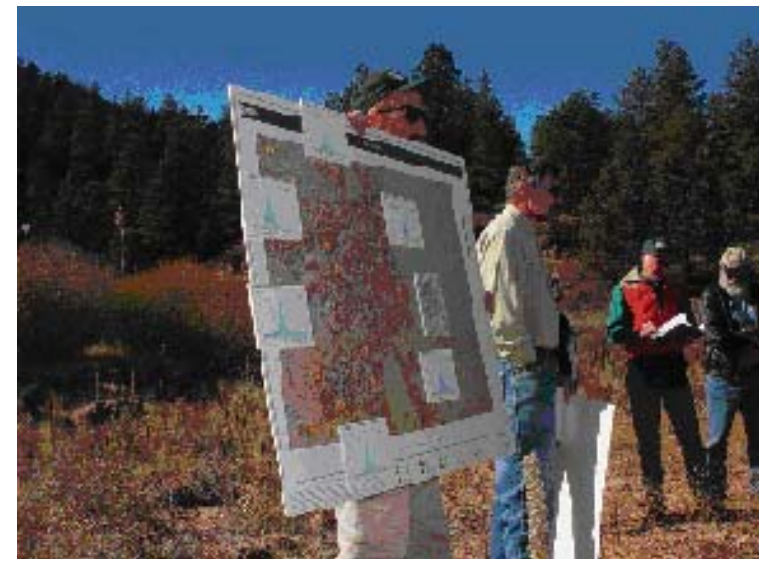

Presentation by Bob Jarrett, Research Hydrologist with the U.S. Geological Survey, during the pre-workshop field trip to the Hayman Fire area.

\section{Keynote Presentations}

During the first day of the workshop, the attendees heard from three key individuals with regard to the fire-science direction of the entire Department of the Interior as well as the USGS. The following is a brief synopsis of those remarks.

\section{Tom Casadevall, Regional Director, Central Region}

The workshop opened with introductory remarks and a summary of fire-science progress since the 2000 workshop in Los Alamos. Casadevall spoke of growing awareness in USGS about the need to focus resources on fire-science activities and the opportunity to use an integrated science approach in this regard. He commented on the National Fire Plan and the role of science in the plan, which he felt was well suited for the USGS. To illustrate recent progress made by the USGS, Casadevall cited the Memorandum of Understanding signed with the Bureau of Land Management and the use of temporary assignments of USGS personnel to the National Interagency Fire Center (NIFC). He closed by talking about the significant progress that has been made despite limited resources and pledged his continuing support through the Regional Partnership Program.

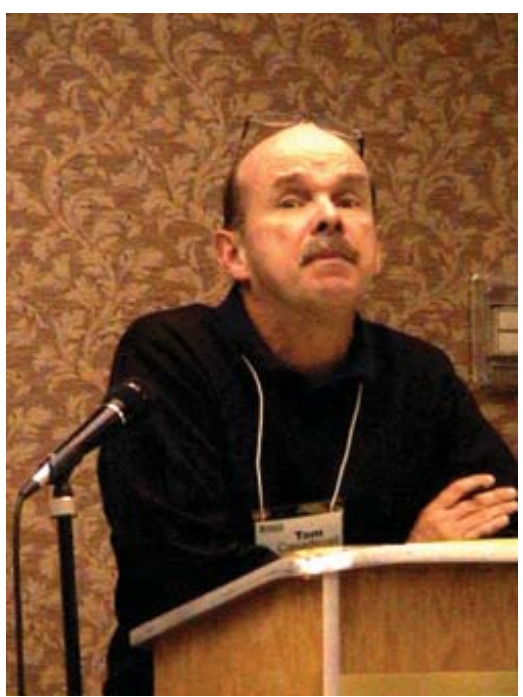

Tom Casadevall, Regional Director, Central Region, U.S. Geological Survey.

Nina Hatfield, Deputy Assistant Secretary for Policy and Budget, Department of the Interior

The keynote address for the workshop, Fire Science and the National Fire Plan, was given by Nina Hatfield. She began her remarks by talking about the opportunities for the Federal community to come together in a collaborative manner in order to balance all the elements in the National Fire Plan. She discussed a number of these elements to which she felt the USGS could appropriately contribute, including monitoring, post-fire rehabilitation, invasive species, carbon cycling, and remotely sensed information. Hatfield felt there was a need for increased accountability and better measures of performance, and she suggested the upcoming evaluation by the Government Accounting Office would be critical relative to the future direction of the USGS and other agencies with regard to the National Fire Plan and wildfire emergency response.

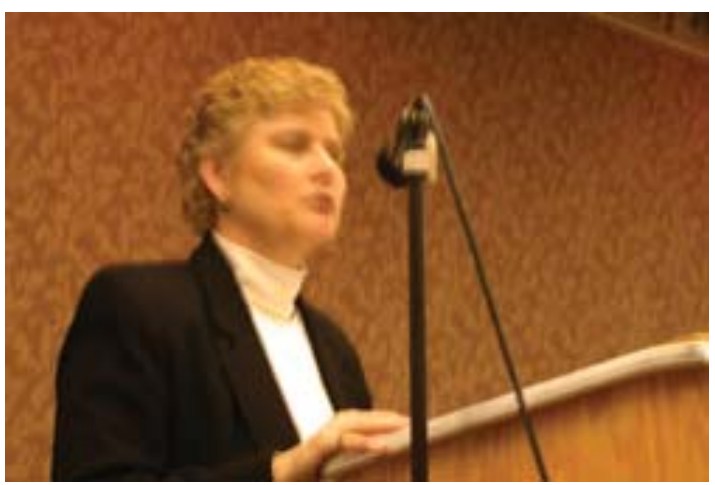

Nina Hatfield, Deputy Assistant Secretary for Policy and Budget, Department of the Interior. 


\section{Chip Groat, Director}

During his luncheon talk, Director Groat began his remarks by acknowledging the partnership of Federal agencies relative to fire science and the ever-expanding role of USGS in that partnership. He spoke of how USGS support before, during, and after wildland fires is providing important assistance to the fire community and the public at large. Research on climate change, fire history, fire ecology, and fuels mapping was cited, providing examples of ongoing contributions that USGS scientists are making to the study of wildland fire. Groat highlighted GeoMAC (Geospatial Multi-Agency Coordination Group) as the kind of tool the USGS can develop and implement to assist agencies in managing fires during the course of a fire season. He emphasized the extensive capabilities of the USGS relative to post-fire assessment, including providing support to BAER teams; mapping burn severity; evaluating the potential for floodflows, debris flow and landslides, and water-quality and sediment effects; and determining the effectiveness of stabilization and rehabilitation activities. In closing, Groat advocated coordination of research efforts to ensure the science is relevant and duplication is avoided as we continue to address the challenges in fire science that are associated with the National Fire Plan and the 10-Year Strategy Implementation Plan. "The challenge," he said, "is how to organize, coordinate, and fund a well-focused and continuing effort to meet these significant needs."

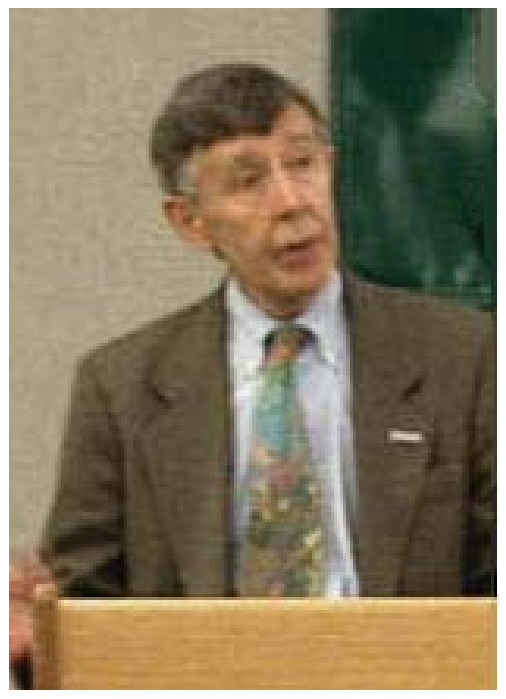

Chip Groat, Director, U.S. Geological Survey.

\section{Panel Discussions}

During the course of the workshop, four panel discussions provided an opportunity for representatives of other Federal and State agencies, as well as nongovernmental entities, to present their views on topics of common interest and concern. The panel topics and presenters were as follows:
- Strengthening USGS' Relationship with Other Federal Agencies Relative to Fire-Science Issues

- Susan Conard, National Program Leader, Fire Ecology Research, USDA Forest Service

- Lee Barkow, Director, National Science and Technology Center, BLM

- Jeff Whitney, Chief, Fire Management Branch, Region 2, FWS

- Tom Zimmerman, Fire Science and Ecology Program, NPS/NIFC

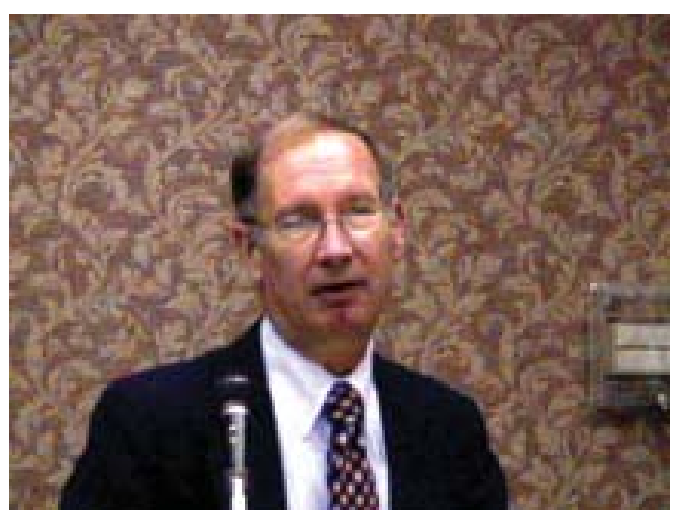

Lee Barkow, Director, National Science and Technology Center, Bureau of Land Management.

- Goals and Organization of a Fire Research Council

- Bob Clark, NIFC/Joint Fire Science Program

- Dave Cleaves, National Program Leader, Fire Science Research, USFS

- Stan Coloff, Fire Coordinator, USGS

- From Researcher to Land/Resource Manager: How Can Technology Transfer Be Improved?-The NonFederal Perspective

o Jim Hubbard, State Forester, Colorado State Forest Service

- Pat Reid, Director of School of Renewable Natural Resources, University of Arizona

- Ayn Shlisky, Landscape Ecologist, The Nature Conservancy

- From Researcher to Land/Resource Manager: How Can Technology Transfer Be Improved?-The Federal Perspective

- Lee Barkow, Director, National Science and Technology Center, BLM 
- Doug Stephen, Fire Planner and Geographical Information Systems Specialist, NPS

- Amanda McAdams, Region 1 Fire Ecologist, FWS

- Craig Allen, Research Ecologist, USGS

- Pete Robichaud, Research Engineer, Rocky Mountain Research Station, Forestry Science Laboratory, USFS

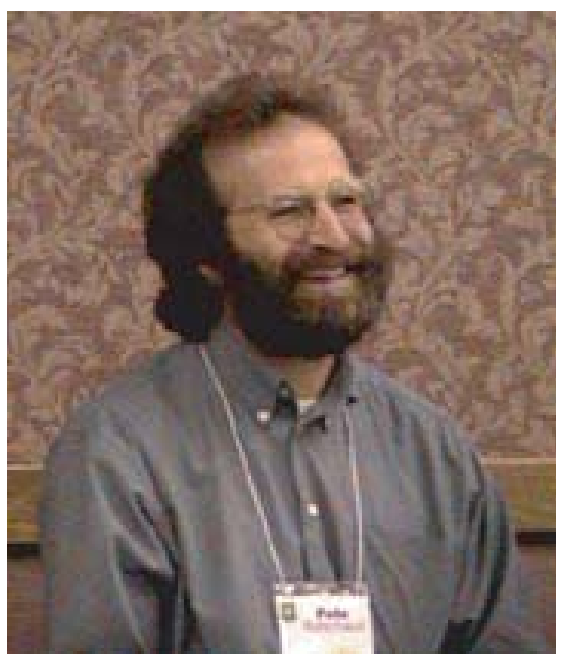

Pete Robichaud, Research Engineer, Forestry Science Laboratory, USDA Forest Service.

\section{Poster Sessions}

One of the highlights of the workshop was a wellattended evening poster session. Abstracts for each of the 30 posters are presented in Appendix D.

\section{White Paper Presentations and Breakout Sessions}

The objective of the "white papers" was to provide a synopsis of ongoing USGS activities, discussion of potential research and collaboration, and recommendations for future actions that could be taken by the USGS to improve our fire science. Four topics were selected for this phase of the workshop:

- Pre-fire risk assessment and fuels mapping

- Post-fire effects, including physical and biological

- Rehabilitation and restoration

- USGS fire response plan

After a presentation by a member of the team that had developed each draft white paper, the subsequent breakout session provided an opportunity for a stimulating and productive environment for the discussion of the content of

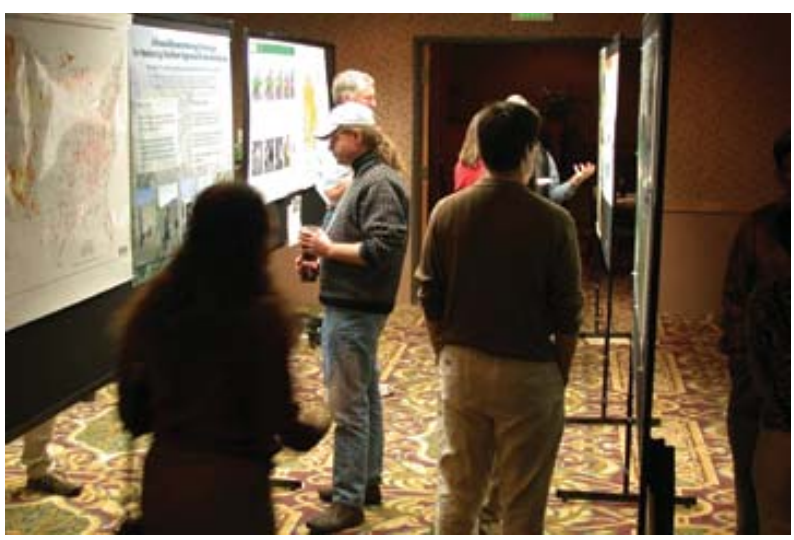

Some of the many attendees of the Poster Session.

each draft white paper and thus led to a more comprehensive document representing the ideas of a broader spectrum of interested parties. As a result of the breakout discussions, the draft white papers were revised; the revised, final versions of these documents are given in Appendices E-H.

\section{Summary and Conclusions}

The overall objective of this workshop was to provide an opportunity for exchange of information on current activities and perceived research needs as the basis for future research and USGS support to other Federal agencies. From a combination of keynote presentations, panel discussions, a field trip, oral and poster technical presentations, and breakout discussions, the attendees came away from the workshop with a general feeling that the workshop was successful relative to accomplishing this objective.

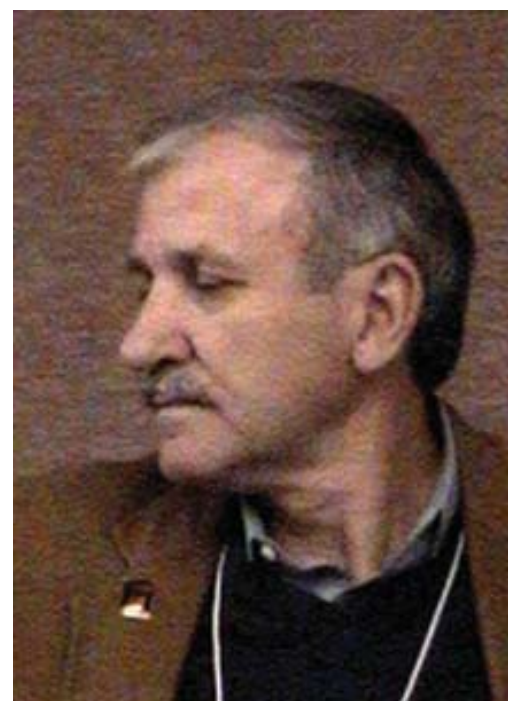

Stan Coloff, Fire Science Coordinator, U.S. Geological Survey. 
Because of the growing interest in wildland fires and the need for proactive and outreach relative to USGS activities and capabilities related to fire science, a Web site has been developed that includes the PowerPoint presentations made during the workshop. This Web site is located at: http://firescience.cr.usgs.gov/html/workshops.html

This site also provides links to Web sites of all Federal agencies involved in wildland fire; information concerning the USGS workshops held in 1997 and 2000; discussion of USGS capabilities, programs, and products; and a directory of USGS offices and scientists.

\section{References Cited}

Coffelt, J.L., and Livingston, R.K., 2002, Second U.S. Geological Survey Wildland Fire Workshop, Los Alamos, New Mexico, October 31-November 3, 2000: U.S. Geological Survey Open-File Report 02-11, 109 p.

Coloff, S.G., Findley, J., and Helz, R.I., 1998, U.S. Geological Survey Wildland Fire Workshop, EROS Data Center, Sioux Falls, South Dakota, July 9-10, 1997: U.S. Geological Survey, Reston, Virginia, 28 p. 
Appendixes A-H 


\section{Appendix A-Agenda for Pre-Workshop Field Trip}

\section{Primary Bus Tour Agenda}

11:00 a.m. Leave Holiday Inn parking lot (Hampden and Wadsworth).

12:15 Arrive at Pine to view USGS streamflow-gaging station.

12:45 Arrive at Community of Buffalo Creek (Bob Jarrett flood discussion).

13:00 Leave Buffalo Creek for Cheesman Reservoir.

13:25 Arrive at Cheesman Reservoir.

13:30-15:00 Walking tour. Specifics of the Hayman burn area including discussion of variable fire burn intensities, soil conditions, biological impacts, invasive species, mitigation efforts by the Denver Water Board, fire mapping efforts by USGS-Geography.

15:00 Leave Cheesman Reservoir.

17:00 Return to Holiday Inn parking lot.

\section{Speakers}

Bob Jarrett, USGS-Water. Fire impacts to flood frequency; discussion of Buffalo Creek flood.

Greg O’Neill, USGS-Water. Brief overview of Colorado drought conditions in water year (WY) 2002.

Dave Grey, USGS-Water. Installation of precipitation gages in the Missionary Ridge burn area.

Greg O’Neill, USGS-Water. Stream gage/turbidity sensor at South Platte at Trumble site.

Deborah Martin, USGS-Water. Overview of wildland fire consequences, including variable effects due to burn intensity, soil types, and so forth.

Sue Cannon, USGS-Geology. Debris flows in the aftermath of the Missionary Ridge fire.

Natasha Kotliar, USGS-Biology. Post-fire biological changes.

Geneva Chong, USGS-Biology. Invasive plant species in post-fire conditions.

Robert Steger, Denver Water Board and Ben Alexander, City of Fort Collins. Wildland fire effects on municipal water suppliers.

Robert Steger, Denver Water Board. Effects of Hayman fire on field operations at Cheesman Reservoir.

Jeff Sloan, USGS-Geography. Geography Discipline products and tools related to pre-fire, post-fire, and during fire events. Specific activities by Geography Discipline for Hayman burn.

Mark Smith or John Elliott, USGS-Water. USGS/FEMA cooperative effort in the aftermath of Hayman fire.

George Leavesley, USGS-Water. Rainfall/runoff modeling efforts, post-fire conditions. 


\title{
Appendix B-Workshop Agenda
}

\section{Third U.S. Geological Survey Fire-Science Workshop}

\author{
"The Role of the USGS in Support of Fire Science \\ and the Implementation of the National Fire Plan"
}

\author{
Holiday Inn \\ 7390 West Hampden Avenue \\ Lakewood, Colorado
}

November 12-15, 2002

Tuesday, November 12, 2002

11:00 a.m.-5:00 p.m. Optional bus tour of Hayman fire area (2002), including review of the nearby Buffalo Creek fire (1996)

Host: Staff of USGS and local cooperating agencies

6:00-7:00 Pre-workshop icebreaker

Cash bar and hors d'oeuvres

Wednesday, November 13, 2002

Morning Session Moderator is Russ Livingston, Fire Coordinator, Central Region, USGS

7:30-8:15 a.m. Continental breakfast in the Huntington Place Room

8:30-9:00 ～Welcome and Opening Remarks: Tom Casadevall, Regional Director, Central Region

9:00-9:30 Presentation: Pre-Fire Risk Assessment, Including Fuels Mapping

Team Leads:

Liz Lile, Cartographer, USGS

Zhi-Liang Zhu, Research Physical Scientist, USGS

Jan van Wagtendonk, Research Forester, USGS

9:30-10:00 Break

10:00-11:15 Panel Discussion: Strengthening USGS' Relationship with Other Federal Agencies Relative to Fire-Science Issues

Panel Members:

Susan Conard, National Program Leader, Fire Ecology Research, USFS

Lee Barkow, Director, National Science and Technology Center, BLM

Jeff Whitney, Chief, Fire Management Branch, Region 2, FWS

Tom Zimmerman, Fire Science and Ecology Program, NPS/NIFC

11:15-11:45 Keynote Address 


\section{Third U.S. Geological Survey Wildland Fire-Science Workshop}

Speaker: Nina Hatfield, Deputy Assistant Secretary for Budget and Finance, Department of Interior "Fire Science and the National Fire Plan"

11:45-1:10 Luncheon (held in the Winner's Circle Restaurant)

Speaker: Chip Groat, Director, U.S. Geological Survey

"USGS Role in Fire Science and Fire Management"

Afternoon Session Moderator is Stan Coloff, Fire Coordinator, USGS

1:10-1:40 Presentation: Post-Fire Effects, Including Physical and Biological

Team Leads:

Matt Brooks, Research Botanist, USGS

Sue Cannon, Research Geologist, USGS

Natasha Kotliar, Research Wildlife, Biologist, USGS

1:40-3:40 Breakout A: Pre-Fire Risk Assessment, Including Fuels Mapping

Breakout B: Post-Fire Effects, Including Physical and Biological

3:40-4:10 Break

4:10-4:30 Breakout “A” Report

4:30-4:50 Breakout "B” Report

6:00-8:00 Social gathering and Poster Session

Cash bar and hors d'oeuvres

\section{Thursday, November 14, 2002}

Morning Session Moderator is Bob Alverts, Science Advisor, Office of the Regional Biologist, Western Region, USGS

7:30-8:15 a.m. Continental breakfast in the Huntington Place Room

8:30-9:30 Panel Discussion: Goals and Organization of a Fire Research Council

Panel Members:

Bob Clark, NIFC/Joint Fire Science Program

Dave Cleaves, National Program Leader, Fire Science Research, USFS

Stan Coloff, Fire Coordinator, USGS

9:30-10:00 Presentation: Rehabilitation and Restoration

Team Leads:

David Pyke, Rangeland Ecologist, USGS

Randy McKinley, Senior Scientist, USGS

10:00-10:30 Break

10:30-11:15 Panel Discussion: From Researcher to Land/Resource Manager: How Can Technology Transfer Be Improved?-The Non-Federal Perspective

Panel Members: 
Jim Hubbard, State Forester, Colorado State Forest Service

Pat Reid, Director of School of Renewable Natural Resources, University of Arizona

Ayn Shlisky, Landscape Ecologist, The Nature Conservancy

11:15-12:00 Workshop photo (location to be determined)

12:00-1:00 Lunch

Afternoon Session Moderator is Stan Ponce, Senior Advisor for Partnerships and Business Policy, USGS

1:00-1:30 Presentation: USGS Fire Response Plan

Team Leads:

Mike Hutt, Cartographer, USGS

Deborah Martin, Research Hydrologist, USGS

Tom Dinardo, Cartographer, USGS

1:30-3:30 Breakout C: Rehabilitation and Restoration

Breakout D: USGS Fire Response Plan

3:30-4:00 Break

4:00-4:20 Breakout "C" Report

4:20-4:40 Breakout "D” Report

4:40 Adjourn

Friday, November 15, 2002

Morning Session Moderator is Joan Fitzpatrick, Deputy Regional Director, Central Region, USGS

7:30-8:15 a.m. Continental breakfast in the Huntington Place Room

8:30-10:00 Panel Discussion: From Researcher to Land/Resource Manager: How Can Technology Transfer Be Improved?-The Federal Perspective

Panel Members:

Lee Barkow, Director, National Science and Technology Center, BLM

Doug Stephen, Fire Planner/GIS Specialist, NPS

Amanda McAdams, Region 1 Fire Ecologist, FWS

Craig Allen, Research Ecologist, USGS

Pete Robichaud, Research Engineer, Rocky Mountain Research Station, Forestry Sciences Laboratory, USFS

10:00-10:30 Break

10:30-11:00 Workshop Summary: Joan Fitzpatrick, Deputy Regional Director, Central Region, USGS

11:00-11:30 Closing Remarks: Tom Casadevall, Regional Director, Central Region

11:30 Adjourn 


\section{Appendix C - List of Workshop Attendees by Agency}

\author{
Bureau of Land Management \\ Barkow, Lee \\ Mazzu, Linda \\ Osborne, Diane \\ Roberts, Thomas \\ Sydoriak, Charisse \\ Federal Emergency Management Agency \\ Brush, Sara \\ Herd, Jeffrey \\ Heyder, Diana \\ Liou, John \\ Government Accounting Office
}

Savage, Megan

Wright, Glenda

National Interagency Fire Center

Arizana, Luther

Clark, Bob

Zimmerman, Tom

National Institute of Standards and Technology

Evans, David

National Park Service

Gardiner, Lisa

Greco, Deanna

Loy, Allen

Stephan, Douglas

\section{U.S. Department of Agriculture, Forest Service}

Cleaves, Dave

Conard, Susan

Garcia, Herman

Lannom, Keith

Nikolov, Ned

Robichaud, Pete

Weise, David

Zachariassen, John

Zeller, Karl

U.S. Department of Agriculture, Cooperative Research

Biles, Larry

U.S. Environmental Protection Agency

Brobst, Bob

\author{
U.S. Fish and Wildlife Service \\ Bottle, Ken \\ Cornman, Ari \\ McAdams, Amanda \\ Whitney, Jeffrey \\ U.S. Geological Survey \\ Adams, Alisa \\ Allen, Craig \\ Alverts, Bob \\ Bauer, Mark \\ Baum, Rex \\ Boyle, Terence \\ Bright, Dan \\ Britton, Linda \\ Brooks, Matt \\ Brown, Karl \\ Cannon, Susan \\ Cannon, William \\ Capesius, Joseph \\ Carswell, William \\ Casadevall, Tom \\ Chong, Geneva \\ Coloff, Stan \\ Costello, Catherine \\ Despain, Don \\ Eidenshink, Jeffrey \\ Elliott, John \\ Eppinger, Robert \\ Ethridge, Max \\ Findley, John \\ Finn, Carol \\ Fitzpatrick, Joan \\ Fleming, Michael \\ Giffin, Carol \\ Gori, Paula \\ Grabner, Keith \\ Grace, Jim \\ Gresswell, Robert \\ Grey, Dave \\ Groat, Chip \\ Haverland, Pam \\ Highland, Lynn \\ Hostetler, Steve \\ Howard, Stephen \\ Hutt, Mike \\ Jarrett, Bob \\ Keeley, Jon \\ Key, Carl \\ Kircher, James \\ Klaver, Jacueline
}




\section{U.S. Geological Survey-Continued}

Klein, Terry

Kokaly, Raymond

Kotliar, Tasha

Kwan, Linn

Lile, Elizabeth

Little, Ed

Livingston, Russ

Manies, Kristen

Martin, Deborah

McGregor, Joe

McKinley, Randy

McWreath, Harry

Moody, John

Murphy, Sheila

Ohlen, Don

Olsen, Randle

Posson, Doug

Pyke, David

Reddy, Michael

Ritz, George

Root, Ralph

Rupert, Michael

Ruth, Janet

Shanks, Bernard

Shroba, Ralph

Slate, Janet

Sloan, Jeff

Smith, Mark

Starkey, Edward

Stephens, Diane

Stephenson, Nathan

Stevens, Mike
Stitt, Susan

Taylor, Jonathan

Teller, Ralph

Thormodsgard, June

Tumbusch, Mary

van Wagtendonk, Jan

Veenhuis, Jack

Ward, Janice

Welborn, Toby

Woodruff, Laurel

Zhu, Zhi-Liang

U.S. Department of the Interior

Hatfield, Nina

Non-Federal Agency Participants

Alexander, Ben City of Fort Collins

Baer, Bill Space Imaging

Carroll, Mark University of Maryland,

Dept. of Geography

Coen, Janice National Center of Atmospheric

Research

Hubbard, Jim Colorado State Forest Service

Matt, Diane

Geological Society of America

Noe, David

$\mathrm{Qu}, \mathrm{John}$

Colorado Geological Survey

Reed, Pat

George Mason University

University of Arizona

The Nature Conservancy

Colorado State University

Geo Management Associates

Warnecke, Lisa

Wright, Kenneth
Wright Water Engineers 


\section{Appendix D-Poster Session Abstracts}

(Listed in alphabetical order by senior author)

\section{Behavior, Effects, and Management in Unburned and Previously Burned Blackbrush (Coleogyne Ramosissima) Shrublands in the Mojave Desert}

Matthew Brooks (matt_brooks@usgs.gov), USGS, Western Ecological Research Center, Las Vegas Field Station, Henderson, Nev. (702-564-4615)

Todd Esque, USGS, Western Ecological Research Center, Las Vegas Field Station, Henderson, Nev. (702-564-4615)

J.R. Matchett, USGS, Western Ecological Research Center, Las Vegas Field Station, Henderson, Nev. (702-564-4615)

The frequency of fire and the size of human populations increased recently in the Mojave Desert, and fire is now a threat to both homes and wildlands in some areas. Land managers need tools to reduce the chance of fire spreading from wildlands into urban areas, and from urban areas, campgrounds, and roadsides into wildlands. Although most desert plant communities do not burn easily, those dominated by blackbrush (Coleogyne ramosissima), invasive annual grasses, or especially those dominated by both, can fuel very large fires. Prescribed fire has been used to reduce woody fuels from blackbrush, but the profusion of fine fuels from invasive annual grasses that typically follow create a new fire hazard and other threats to ecosystem integrity. Management tools are needed to reduce existing fire hazards but not create new hazards or threaten natural resources. This study will document the behavior and ecological effects of fire and evaluate the use of fire and mechanical thinning to reduce woody fuel loads from blackbrush, and fire and herbicides to reduce fine fuel loads from invasive annual grasses. Preliminary, pretreatment plant data from spring 2001 in unburned and previously burned (9-15 years post-fire) blackbrush vegetation at Joshua Tree National Park, Calif., Spring Mountains, Nev., and Beaver Dam Mountains, Utah, found previous burns reduced

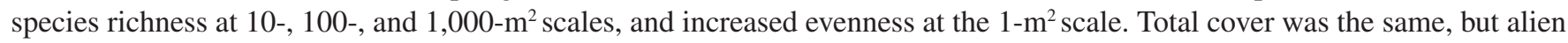
annual plant cover was 191 percent higher and native cover was 26 percent lower in burned than unburned areas. Results varied among the three sites, reflecting the difficulty in predicting patterns of post-fire plant succession in blackbrush scrub vegetation. 


\section{Tools and Methodologies for the Prediction of Post-Wildfire Debris-Flow Activity and Hazard Delineation}

Susan H. Cannon (cannon@usgs.gov), USGS, Central Region Hazards Team, Denver, Colo. (303-273-9604)

Alan Rea (ahrea@usgs.gov), USGS, Boise, Idaho (208-387-1323)

Chuck Parrett (cparrett@usgs.gov), USGS, Helena, Mont. (406-457-5928)

Kenneth L. Pierce (kpierce@ usgs.gov), Northern Rocky Mountain Science Center, Bozeman, Mont. (406-994-5085)

Joseph E. Gartner (jegartner@ usgs.gov), USGS, Central Region Hazards Team, Denver, Colo. (303-273-9604)

Debris flows can be some of the most destructive hazards to impact an area after a wildfire. Recent fires throughout the Western United States have burned hundreds of thousands of acres of mountainous terrain (much of which is public land) and made it susceptible to increased debris-flow activity. The millions of dollars spent yearly to mitigate the effects of wildfire points to the need to develop tools to identify and quantify the potential hazards posed by debris flows produced from burned watersheds.

The focus of this project is to develop tools and methodologies for the prediction of post-wildfire debris-flow activity and hazard delineation. Land-management agencies dealing with post-wildfire rehabilitation and emergency planning need tools to determine both the probability and the magnitude of such potentially destructive events from individual drainage basins. We are developing GIS-based approaches for assessing debris-flow hazards from recently burned watersheds based on combinations of data and information readily available immediately following wildfires. In addition, we have established a monitoring network for the collection of post-wildfire peak runoff and rainfall data from basins burned during the summers of 2000 and 2001 . These data are being used to develop multivariate statistical models that relate peak runoff to rainfall rates, basin morphology, soil physical properties, and burned extent. These models can be combined with digital elevation models (DEMs) to delineate the probability of fire-related debris-flow susceptibility and the magnitude of the response.

We also are working to develop models for fire-related debris-flow initiation processes. The great majority of fire-related debris flows initiate by a process of progressive bulking of storm runoff with sediment eroded from hillslopes and channels rather than by failure of discrete landslides. The focus of this task is to conduct field and theoretical studies of the mechanics of this process of debris-flow initiation. These studies will lead to the development and calibration of physically based models for debris-flow movement that can be used to predict the volume of material that can be eroded from hillslopes and channels for given rainfall conditions. The contribution of material eroded from hillslopes and channels to runoff events is a critical issue in post-wildfire hazard assessments as well as nonfire-related events. 


\section{MODIS Land Rapid Response System Near Real-Time Global Land Surface Observations}

Mark Carroll (markc@ geog.umd.edu), Department of Geography, University of Maryland, College Park, Md. (301-405-9410)

Christopher Justice (justice@ hermes.geog.umd.edu), Department of Geography, University of Maryland, College Park, Md. (301-405-1600)

The MODIS (Moderate Resolution Imaging Spectroradiometer) Land Rapid Response system was designed to provide rapid access to imagery for wildfires, flooding, and other natural hazards in the United States and around the world. The primary focus inside the United States has been on fire applications. For the past two fire seasons, MODIS Rapid Response has provided active fire location points to the USFS Remote Sensing Applications Center (RSAC) for the daily production of fire maps throughout the United States. Expanded efforts have included development of a Web-based GIS server to make the fire location data available to the Global Community. Outreach activities through the Global Observation of Forest Cover (GOFC/GOLD) community have been warmly received in countries from South America to Australia and Africa. Continued work includes incorporating Direct Broadcast users into this community. To this end, the Rapid Response code has been packaged and made available free of charge to all Direct Broadcast users. 


\section{Post Wildfire Hazard Reconnaissance Maps}

C. Costello (ccostello@usgs.gov), USGS, Lakewood, Colo. (303-202-4008)

S.R. Wilds (srwilds@usgs.gov), USGS, Lakewood, Colo. (303-202-4073)

M.E. Smith (mesmith@usgs.gov), USGS, Lakewood, Colo. (303-236-4882)

R.S. Parker (rsparker@usgs.gov), USGS, Lakewood, Colo. (303-236-4882)

D. Bausch (douglas.bausch@ fema.gov), Federal Emergency Management Agency, Region 8, Lakewood, Colo. (303-235-4859)

T. Browning (tom.browning@ @ state.co.us), Colorado Water Conservation Board, Denver, Colo. (303-866-4804)

In response to a need to conduct a statewide emergency management and risk assessment, the USGS was tasked by the Post Wildfire Hazards Inter-Agency Group to construct maps covering the sixteen most critical 2002 Colorado wildfire incidents (as of July 1, 2002). These maps, called Post Wildfire Hazard Reconnaissance Maps, were used by Federal, State, and local emergency management agencies to assess the risks to lives and property from potential flood and debris-flow processes.

The USGS approached this task by assembling a variety of geospatial data sets in a Geographic Information System (GIS) from which a variety of map and statistical products were delivered. The reconnaissance maps depict the fire burn perimeter and burn severity (provided by the USGS and the USFS) overlain on a topographic and planimetric base. Their purpose was to show the location and proximity of the burn area to a variety of natural and man-made features, as well as FEMA's Flood Insurance Rate Maps (FIRMs). The reconnaissance maps help prioritize areas where more detailed hydrologic and hydraulic analyses were needed. These maps were distributed to FEMA, the Colorado Water Conservation Board (CWCB), county governments, and the Colorado Office of Emergency Management (OEM) within 15 days of the President's Disaster Declaration for Colorado. Data sets used for the GIS and reconnaissance maps were provided by a variety of sources, including FEMA, county governments, USDA Forest Service, and the USGS. The data sets include:

- Digital Raster Graphics (DRGs) with updated transportation and structures from 1999 Digital Orthophoto Quads (DOQs)

- Digital Elevation Models (DEMs, 10 meter and 30 meter) and derived products such as slope, aspect, and shaded relief

- Hydrologic Unit Catalog boundaries

- Subdivision names and perimeters

- Flood Insurance Rate Map (FIRM) index information

- Burn perimeters

- Burn severity

- Potential Hazard Area delineations

Detailed analysis has already begun on the Hayman burn area and will be expanded to include the Missionary Ridge burn site near Durango and the Coal Seam burn site near Glenwood Springs in fiscal year 2003. 


\title{
Rocky Mountain Mapping Center Wildfire Activities
}

\author{
C. Costello (ccostello@usgs.gov), USGS, Lakewood, Colo. (303-202-4008)
}

S.R. Wilds (srwilds@usgs.gov), USGS, Lakewood, Colo. (303-202-4073)

R. Root (Ralph_Root@USGS.gov), USGS-Geography, Lakewood, Colo. (303-202-4339)

E. Lile (ellile@usgs.gov), USGS-Geography, Lakewood, Colo. (303-202-4326)

J.L. Sloan (jlsloan@usgs.gov), USGS-Geography, Lakewood, Colo. (303-202-4118)

Post Fire Reconnaissance Maps. - In response to a need to conduct a statewide emergency management and risk assessment, the USGS was tasked by the Post Wildfire Hazards Inter-Agency Group to construct maps covering the most catastrophic 2002 Colorado wildfire incidents. The USGS approached this task by assembling a variety of geospatial data sets in a Geographic Information System (GIS) from which a variety of map and statistical products were delivered. The maps depicted the fire burn perimeter, burn severity, the location and proximity of the burn area to a variety of natural and man-made features, as well as FEMA's Flood Insurance Rate Maps (FIRMs). The maps helped prioritize areas where more detailed hydrologic and hydraulic analyses were needed. Detailed analysis is underway for the Hayman site and will be expanded to include the Missionary Ridge and the Coal Seam sites.

Wildfire Incident Support.-The Rocky Mountain Mapping Center (RMMC) has been providing the Federal landmanagement agencies with mapping support related to wildland fire-suppression efforts for several years. Initial efforts involved the development of an integrated geospatial data set for Incident Commands (ICs) and strategic fire-planning activities. Underpinning these efforts has been the need for GIS Incident Tactical Support primarily in the form of medium to large-scale maps and corresponding digital data. Unfortunately, a great deal of these maps in high risk fire areas, such as in the wildland/urban interface, do not depict a current representation of the local area. The initial goal is to provide the Incident and Coordination Centers with current information on transportation networks, structures, and subdivisions.

GeoMAC (Geospatial Multi-Agency Coordination Group) 2002.-GeoMAC is hosted by the USGS under the direction of the National Interagency Fire Center (NIFC). The audience for the 2002 fire season was the wildland fire public affairs officers and the public. The project objective is to provide geospatial information related to the areas being affected by wildfires through a Web interface. Data content of the site included: thermal imagery, such as MODIS (Moderate Resolution Imaging Spectroradiometer) or AVHRR (Advanced Very High Resolution Radiometer), situation report fire locations, RAWS (Remote Automated Weather Station) data, fire perimeters, and base-layer information. The GeoMAC site received over 50 million requests this summer.

The Advanced Remote Sensing Technologies for Monitoring Post-Burn Vegetation Trends and Conditions.— This project is designed to apply several newly developed remote-sensing techniques to accurately describe the temporal dynamics of vegetation community composition in a shrub-grassland ecosystem following prescribed fire treatments. Imaging spectroscopy is used to estimate both the biomass and moisture content of vegetation canopies, specifically grassland and shrub fuel types. We propose to develop this state-of-the-art information as input into fire-behavior and fire-danger rating models. 


\section{Hazards from the 2002 Hayman, Missionary Ridge, and Coal Seam Wildfire Areas, Colorado}

J.G. Elliott (jelliott@usgs.gov), USGS, Lakewood, Colo. (303-236-4882)

M.E. Smith (mesmith@usgs.gov), USGS, Lakewood, Colo. (303-236-4882)

S.H. Cannon (cannon@usgs.gov), USGS, Golden, Colo. (303-273-8604)

C. Costello (ccostello@usgs.gov), USGS, Lakewood, Colo. (303-202-4008)

J. Wagner (jwagner@do.usbr.gov), Bureau of Reclamation, Lakewood, Colo. (303-445-3136)

The 2002 wildfires in Colorado left thousands of square kilometers of rugged forest land vulnerable to rapid rainfall runoff and erosion. The greatest threat to areas within and downstream from the burned areas at present (2002) is from flooding and debris flows. Three disciplines of the U.S. Geological Survey (Water, Geologic, and Mapping) and the Bureau of Reclamation (Water Conveyance Group) are collaborating to quantify the increased post-fire hydrologic hazards from the Hayman, Missionary Ridge, and Coal Seam fires. The Federal Emergency Management Agency will use this work to reevaluate flood- and debris-flow hazard maps in populated areas. Initial post-fire assessments of the three burned areas determined that flooding by sediment-laden water is the primary hazard along the main stem of the South Platte River in the Hayman area (Colorado Front Range) and along Mitchell Creek in the Coal Seam area (Glenwood Springs, Colo.). Debris flows are the primary hazard in smaller, perennial and ephemeral streams in the Coal Seam and Missionary Ridge (Durango, Colo.) areas.

Post-fire flood depths for the 100-year peak discharge are being estimated by calculating runoff from tributaries to the South Platte River and Mitchell Creek with the WMS/HEC-1 computer model. Tributary runoff characteristics are estimated by using the Soil Conservation Service Runoff Curve Number that accounts for soil characteristics, vegetation cover, and antecedent moisture conditions. Modeled runoff is calibrated to pre-fire discharge data from gages in or near the study area, then modified to reflect post-fire conditions, and finally adjusted for the anticipated increased sediment yield. Sediment yields are estimated by using relations derived by Moody and Martin from studies of the 1996 Buffalo Creek fire (Colorado Front Range). Watershed characteristics such as elevation, slope angle, and the percentage of the watershed area that sustained a moderate or high burn severity are determined from satellite imagery and digital elevation models.

Potential debris-flow peak discharges are being estimated from watershed characteristics derived from digital elevation models, burn-severity maps, and the model developed by Cannon that relates debris-flow peak discharge to different measures of basin gradient and the extent of the burned area. Peak discharges estimated by this approach will be used as input to the Flo-2D two-dimensional flood-routing model to generate maps of debris-flow inundation on alluvial fans. 


\section{Comparing Pre- and Post-Wildfire Stream Sediment and Water Geochemistry from Drainages Impacted by the Clear Creek and Wilderness Complex Wildfires of 2000, Central Idaho}

Robert Eppinger (eppinger@ usgs.gov), USGS, Denver, Colo. (303-236-2468)

Paul Briggs, USGS, Denver, Colo. (303-236-2453)

Betsy Rieffenberger, USDA Forest Service, Salmon, Idaho (208-756-5108)

Carol Van Dorn, USDA Forest Service, Challis, Idaho (208-879-4160)

A USGS baseline stream sediment and water geochemical study was undertaken in central Idaho in 1996. The intent of the study was to provide a geochemical "snapshot" of the area, as an aid to managing land-use activities. In 2000, much of the area sampled was burned by the Clear Creek (>206,000 acres) and Wilderness Complex (>182,000 acres) fires. The area was resampled in 2001 to assess changes caused by the wildfires, in a study jointly funded by the USGS Minerals Program and Salmon-Challis National Forest.

Samples were collected during 3-week periods in July 1996 and in June 2001. In both studies, bedload stream sediment and stream-water samples were collected from main river channels and major tributaries at 93 coincident sites along Panther Creek, the Middle Fork of the Salmon River, and a portion of the Main Salmon River. While time constraints precluded the following of strict USGS Water Resources Discipline ppb-protocol water-sampling procedures, clean procedures were used throughout. Quality-assurance/quality-control concerns were addressed through the use of site duplicates, analytical duplicates, and standards. Mixed-water samples were obtained by width-integrated collection below riffles. Waters and minus- 80 mesh stream sediments were analyzed for a broad suite of elements by ICP mass spectrometry, ICP emission spectrometry, and ion chromatography.

Nonparametric Wilcoxon matched pair and sign tests were used to determine statistically significant differences between the pre- and post-wildfire data sets. For stream sediments, no statistical differences ( $p$-levels $>0.05$ ) were found for $\mathrm{Bi}, \mathrm{Ca}$, $\mathrm{CO}_{3}^{-}$, $\mathrm{Ce}, \mathrm{Fe}, \mathrm{Ho}, \mathrm{K}, \mathrm{La}, \mathrm{Nb}, \mathrm{Nd}, \mathrm{Sb}, \mathrm{Te}$, Th, or Ti. However, post-wildfire sediments are more enriched $(p$-levels $<0.05)$ in the major elements $\mathrm{Al}$, organic $\mathrm{C}$, total $\mathrm{C}$, and $\mathrm{Mg}$, and the trace elements $\mathrm{Ba}, \mathrm{Co}, \mathrm{Cu}, \mathrm{Li}, \mathrm{Mn}, \mathrm{Ni}, \mathrm{Pb}, \mathrm{Sc}, \mathrm{V}$, and $\mathrm{Zn}$. In contrast, stream sediments collected prior to the wildfires are slightly enriched $(p$-levels $<0.05)$ in As, $\mathrm{Na}$, and Sr. Higher total $\mathrm{C}$ and organic $\mathrm{C}$ (the main component of total $\mathrm{C}$ ) in post-wildfire stream sediments is explained by the abundant charcoal observed in stream sediments at most sites downstream from burned areas. In post-wildfire sediments, higher concentrations of the rockforming elements, such as $\mathrm{Al}, \mathrm{Ba}, \mathrm{Li}, \mathrm{Mg}, \mathrm{Mn}, \mathrm{Sc}$, and $\mathrm{V}$, are likely the result of additional sediment from debris flows following the wildfires. The trace elements $\mathrm{Co}$ and $\mathrm{Cu}$ are highest in stream sediments collected from Panther Creek and below it along the Main Salmon River. Panther Creek contains As-bearing Co-Cu mineral deposits, and sediments downstream reflect the presence of these deposits. Much of the mineralized ground burned in 2000. It is unclear from the present data why As behaves differently from $\mathrm{Co}$ and $\mathrm{Cu}$ in pre- and post-wildfire sediments.

For stream-water samples, no statistical differences ( $p$-levels $>0.05$ ) were found for the major ions $\mathrm{Ca}, \mathrm{F}^{-}, \mathrm{K}, \mathrm{Mg}, \mathrm{Na}$, and $\mathrm{Si}$, indicating no significant changes between the two sampling periods. Stream waters from 1996 were variably higher in tem-

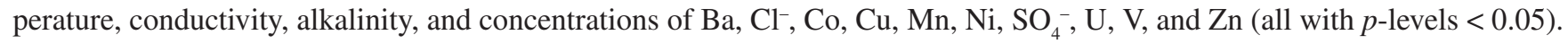
These effects may be attributed to the fact that waters collected in early June of 2001 were dilute compared to those collected in mid-July of 1996. Effects of wildfire on stream-water compositions were not observed in samples collected 10 months later. 


\section{How Do Wildfire, Granivores, and Alien Annual Grasses Change Mojave Desert Seed Banks?}

Todd C. Esque (todd_Esque@ usgs.gov), USGS, Western Ecological Research Center, Henderson, Nev. (702-564-4506)

Persistent seed banks represent the current and future potential of annual plant populations in the Mojave Desert. Fluctuations in plant populations are reflected in the seed bank, particularly when severe disturbances occur. In this experiment, we manipulated the presence and absence of granivorous ants and rodents and fire to understand mechanisms of changes in Mojave desert scrub annual plant populations, particularly with respect to the alien annual grasses: red brome (Bromus madritensis ssp. rubens) and split grass (Schismus spp.). Experimental data are compared to seed bank dynamics across landscapes. When averaged across microsites, annual plant species richness was significantly greater on unburned sites than burned sites and among years, but not among granivore treatments. Seed bank richness was greater on unburned sites and was likely due mostly to variable precipitation among years. Native species had greater density on unburned plots and also varied significantly among years. Preliminary data suggest that high intensity or sequential fires with short return times in combination with alien annual grass increases after fire may drive native seed banks toward local extinctions. 


\section{Physics-Based Urban Wildland Interface Fire Modeling}

David Evans (dave.evans@ nist.gov), Building and Fire Research Laboratory, National Institute of Standards and Technology, Gaithersburg, Md.

Ronald Rehm, Building and Fire Research Laboratory, National Institute of Standards and Technology, Gaithersburg, Md.

Lisa de Jong, USDA Forest Service, Center for Urban Forest Research, c/o Dept. of Environmental Horticulture, University of California, Davis, Calif.

Gregory McPherson, USDA Forest Service, Center for Urban Forest Research, c/o Dept. of Environmental Horticulture, University of California, Davis, Calif.

Amarilis Puig, Riverside Forest Fire Laboratory, Pacific Southwest Research Station, Riverside, Calif.

Fires initiated in wildland areas can spread to populated areas where structures can be ignited (UWI fires). The onset of burning structures introduces fire intensities and durations different from that produced by vegetation. Community fire spread and the risk of ignition for homes exposed to both burning vegetation and other structures are complex. As the geometry and types of fuels are dictated by landscaping instead of larger scale wildland fuel beds, fire models need to be constructed to account for the ignition and burning characteristics of individual fuel elements, such as trees, shrubs, decks, building siding, windows, and roofs.

Quantifying the benefits and hazards associated with urban vegetation and its placement on property is part of the research program of the Forest Service Pacific Southwest Station, Center for Urban Forest Research. The Center and its partners are developing a Web-based quantitative tool for use by property owners to make informed decisions about landscape design and management relative to energy conservation, hydrology, and fire safety. 


\section{k_NN Mapping of Fire-Fuel Parameters Using Satellite Imagery and Field Data from Forest Inventory Plots}

Michael D. Fleming (fleming@usgs.gov), USGS, Anchorage, Alaska (907-786-7034)

Zhi-Liang Zhu (zhu@usgs.gov), USGS, Sioux Falls, S. Dak. (605-594-6131)

Michael Hoppus (mhoppus@fs.fed.us), USDA Forest Service, Newtown Square, Pa.

This project was designed to study techniques and prototype methodologies for mapping meaningful vegetation parameters that can be used as input variables to fire-management systems, such as FARSITE. Satellite remote-sensing data may be effectively used to model and map the natural vegetation types and vegetation structure classes that are essential elements of fire-fuels characterization. The k_Nearest Neighbor (k_NN) classification algorithm was evaluated for several parameters to yield the most useful data for fuels mapping.

When classifying pixel " $\mathrm{x}$ ", the $\mathrm{k} \_N N$ algorithm finds the training plots that are most similar to $\mathrm{x}$ and chooses the class prevailing among these plots, where $\mathrm{k}$ is the number of nearest training plots. The algorithm can utilize any continuous variable for training and classification and output continuous or class values. Previous studies using a k_NN classifier, usually to characterize land cover, have not evaluated several key input parameters for best results, especially for fire-fuels mapping. This study was conducted with the $\mathrm{k} \_\mathrm{NN}$ algorithm to evaluate the size of the sample to use (number of plots), the number of neighbors (k), and the number and combination of spectral bands and dates of satellite data, from three seasons of imagery. Several additional input variables, including topography (elevation, slope, aspect, topographic position) and soils (available water content, organic carbon, and a quality index) were examined.

The k_NN algorithm and the results of the parameter evaluation were used to map the spatial distribution of several key vegetation variables by integrating USDA Forest Service Forest Inventory and Analysis (FIA) field survey plot data with Landsat-7 Enhanced Thematic Mapper Plus (ETM+) remote-sensing imagery. Mapping results were evaluated using several methods, including a field evaluation of the classifications. The results displayed in the graphs and the table are from the analysis of a Chesapeake Bay test site. The map examples are from a southern Utah test site. Forest type classes were successfully mapped, along with estimates of basal area of coniferous and deciduous forest, total above-ground biomass, crown cover, tree height, and forest size class (saplings, pole, and saw timber). The research results will be useful for science and landmanagement agencies to map fire fuels with remotely sensed data for predicting fire behavior using models such as FARSITE. 


\section{Reducing Losses from Landslides-A National Mitigation Strategy}

Paula L. Gori (pgori@usgs.gov), USGS, Reston, Va. (703-648-6707)

Landslide losses in the United States amount to as much as $\$ 3$ billion annually. Losses occur in every State and involve Federal, State, and private lands. The Stafford Act (1974 Disaster Relief Act, 42 U.S.C. 5201 et seq.) assigns USGS responsibility to provide landslide warnings to emergency management authorities and the public in order to reduce losses. In 1999, the U.S. Congress directed the USGS to develop a comprehensive strategy to address landslide hazards and involve the parties having responsibility for dealing with the problems in the planning process. The strategy that was developed is outlined in a report entitled "National Landslide Hazards Mitigation Strategy: A Framework for Loss Reduction" (USGS Open-File Report 00-0450), which is the culmination of a coordinated effort of USGS, State, university, and private-sector partners to formulate a national loss-reduction strategy. The report is available at: http://geology.cr.usgs.gov/pub/open-file-reports/ ofr-00-0450/

Annual funding estimates for implementation of the National Landslide Hazard Mitigation Strategy, as outlined in USGS Open-File Report 00-0450, are:

- USGS Research, Monitoring, and Assessment (+\$10 M): USGS would (1) expand research on physical processes and develop new probabilistic landslide hazard maps and predictive models for populous and landslide-prone regions in the Pacific Northwest, California, the Appalachians, and Puerto Rico; (2) design and implement a coordinated rapid response capability; (3) expand assessments of the impacts of wildfires on landslide susceptibility; and (4) expand real-time monitoring. ( $\$ 2 \mathrm{M}$ will be devoted to work by USGS scientists on Federal lands including land managed by the National Park Service, USDA Forest Service, and Bureau of Land Management.)

- State and Territory Agency Grants (+\$8 M): A matching-fund grants program with State agencies would be put in place similar to the STATEMAP component of the National Cooperative Geologic Mapping Act (US Public Law 106-148). Under such a program, States and Territories determine their own priorities, and a national review panel made up of representatives of participating State agencies and USGS sets amounts of grants.

- University Research and Private-Sector Grants $(+\$ 2 \mathrm{M})$ : A university and private-sector research grant program similar to the Earthquake Hazards External Grant program would be started to augment research capabilities in engineering geology, to increase understanding of landslide processes, and to ensure local participation in loss reduction.

The National Research Council (NRC) of the Academy of Sciences is currently assessing the National Landslide Hazards Mitigation Strategy as outlined by the USGS in Open-File Report 00-0450, and their interim report gave a favorable review of the strategy. 


\section{Integrating Fuel and Forest Management: Developing Prescriptions for the Central Hardwoods Region}

Keith W. Grabner (atmokg@usgs.gov), USGS, Northern Prairie Wildlife Research Center, Missouri Field Station, Columbia, Mo. (573-882-0211)

Edward F. Loewenstein (loewenstein@auburn.edu), Assistant Prof. of Silviculture, Auburn University, Auburn, Ala.

George W. Hartman (hartmg@mail.conservation.state.mo.us), Fire Ecologist, Missouri Department of Conservation, Columbia, Mo.

Erin R. McMurry (ermfcd@mizzou.edu) and Jeremy J. Kolaks (jjkea1@ mizzou.edu), Graduate Research Assistants, School of Forestry, University of Missouri, Columbia, Mo.

The oak-hickory forests of the Missouri Ozarks have developed under the influence of fire for thousands of years. Historical Ozark forest conditions were described by early explorers as open forests, thinly scattered trees, and rich in grasses and wildflowers. In the 20th century, fire exclusion, open range grazing, and timber harvesting have modified the forest vegetative structure and fuel loads. In comparing current (2002) and historical Ozark forest conditions, four general differences are noted: (1) tree density has increased; (2) midstory and shrub layers have developed; (3) shortleaf pine densities have decreased; and (4) ground cover has changed from predominantly grasses and forbs to leaf litter and shade-tolerant forbs. We are initiating a study to quantitatively evaluate the effects of prescribed fire—with and without partial overstory removal—on fuel reduction, fire behavior, and vegetation composition and structure within the Missouri Ozarks. The project will facilitate the evaluation and development of fuel-reduction methods for the Ozarks and the effects of those methods on fuel, fire behavior, ground flora, and understory and overstory woody plants. 


\section{The Firelogger: A Compact, Inexpensive Device for Measuring Wildland Fire Temperatures}

James B. Grace (Jim_Grace@usgs.gov), USGS, National Wetlands Research Center, Lafayette, La. (337-266-8632)

Arlene Billock, Johnson Controls Inc., USGS, National Wetlands Research Center, Lafayette, La.

Larry Allain, USGS, National Wetlands Research Center, Lafayette, La.

Continuous recording of fire temperatures by using data loggers and thermocouples has historically been expensive and cumbersome, limiting the widespread use of such technology. This paper describes techniques for measuring fire temperatures that are based on recently developed loggers that are compact and relatively inexpensive. The data logger-thermocouple combinations described in this paper are easy to deploy and provide a wide range of options for routine measurement of fire temperatures in the field. 


\section{Precipitation Stations in the Missionary Ridge Burn Area, Southwestern Colorado}

David Grey (dwgrey@usgs.gov), USGS, Durango, Colo. (970-247-4140)

Mark Gress (magress@usgs.gov), USGS, Durango, Colo. (970-247-4140)

Jennifer Cillessen (jlcilles@usgs.gov), USGS, Durango, Colo. (970-247-4140)

Brandon Thurston (bmthurst@usgs.gov), USGS, Durango, Colo. (970-247-4140)

In July of 2002, the Burn Area Emergency Rehabilitation team and the La Plata County Office of Emergency Response recognized the potential for flooding and debris flows from the severely burned areas in the Missionary Ridge Complex fire. In response to this concern, the U.S. Geological Survey installed and maintained an early warning system of 12 satellite-telemetered precipitation gages. This poster describes the logistics involved with the installation, operation, and maintenance of the system. In addition, included on the poster is a description of the equipment used in the network and the sequence of programming that was necessary to take the rainfall data and make it available to the La Plata County Office of Emergency Response, the National Weather Service, and the public on a real-time basis. The special requirements to deploy the network in nearly inaccessible areas as well as the importance of installing the system as quickly as possible also are described. Also included is a section on how operation and maintenance of the network is handled and a brief discussion of lessons learned from the experience. 


\section{Fire and Exotics in the Mojave Desert: An Irreversible Change? A State- Transition Model for Blackbrush (Coleogyne Ramosissima) Habitat}

D.F. Haines (Dustin_Haines@usgs.gov), USGS, Henderson, Nev. (702-564-4508)

T.C. Esque (Todd_Esque@usgs.gov), USGS, Henderson, Nev. (702-564-4506)

L.A. DeFalco (Lesley_DeFalco@usgs.gov), USGS, Henderson, Nev. (702-564-4507)

S.J. Scoles (sscoles@usgs.gov), USGS, Henderson, Nev. (702-564-4624)

M.L. Brooks (Matt_Brooks@usgs.gov), USGS, Henderson, Nev. (702-564-4615)

R.H. Webb (rhwebb@usgs.gov), USGS, Tucson, Ariz. (520-670-6671)

Several species of invasive exotic plants are ubiquitous in the Mojave Desert and have the potential for increasing fire frequency. Some, such as red brome (Bromus madritensis), occur in sufficient densities to provide continuous fine fuel in intershrub spaces, encouraging the spread of fire over large areas. Positive feedbacks between fire and exotics have been observed in some areas; exotics return in higher densities after a fire, increasing susceptibility to future fires. Our goal is to describe a state-andtransition model for blackbrush (Coleogyne ramosissima) habitat in the Mojave Desert. Areas that have burned once usually have a higher biomass of exotic species, different species composition, and less perennial cover than adjacent unburned habitat for burns as much as 50 years old. Blackbrush recovery is very slow and could take millennia in a once-burned area. Some areas that have burned more than once appear to have been converted from desert scrub to annual grassland, with exotics dominating the landscape between scattered native perennials. While once-burned areas often show signs of native species recovery, areas with multiple burns typically show little natural recovery. Annual exotic grasslands may require significant environmental changes for transition reversal to occur, and the transition from desert scrub to annual grassland may be irreversible under the current climatic regime. 


\section{Multiscale Climatic Controls of Fire in the Western United States: From the Atmosphere to Ecosystems}

Steve Hostetler (steve@ coas.oregonstate.edu), USGS, Corvallis, Ore. (541-737-8928)

Patrick Bartlein (bartlein@oregon.uoregon.edu), Department of Geography, University of Oregon, Eugene, Ore. (541-346-4967)

Allen Solomon (solomon@cor.epa.gov), U.S. Environmental Protection Agency, Corvallis, Ore. (541-754-4772)

Sue Ferguson (sferguson@fs.fed.us), USDA Forest Service, Seattle, Wash. (206-732-780)

Sarah Shafer (sshafer@usgs.gov), USGS, Corvallis, Ore. (541-754-4498)

The dependence of fire on current and antecedent weather conditions is relatively well understood, and this understanding forms the basis of hourly-to-weekly predictions of fire behavior. In contrast, relations between climate (i.e., monthly to multiannual variations of atmospheric circulation) and fire are less well understood. Our research focuses on decomposing and quantifying the hierarchy of climatic controls that influence surface-climate conditions prior to and during the fire season in the Western United States. We are employing an approach in which we will examine and jointly analyze observational (and simulated, or "reanalysis") records of climate (including both observed and "reanalysis" data) and historical records of fire using (1) data-analytical procedures employed in climate-diagnostic studies, and (2) a hierarchy of appropriate regional climate and vegetation models. Through this hierarchical approach, we are quantifying climate-fire relations, evaluating scaling issues associated with the use of atmospheric models in fire research, and initiating research aimed at linking long-term climate to ecosystem responses with the goal of understanding the potential role of climate in natural restoration and reduction of fuel loading.

In our poster, we will demonstrate our joint analyses of synoptic and regional scale climate fields and historical fire records (1986-96) from the Western United States. We also will present preliminary modeling results that quantify the climatic conditions that led to the 2002 fires in the Southwest United States and to the Biscuit fire in southwestern Oregon. 


\section{Historical Fire-Severity Mapping from Landsat Data}

S.M. Howard (smhoward@usgs.gov), Raytheon Information Technology and Scientific Services, EROS Data Center, Sioux Falls, S. Dak. (605-594-6027)

D.O. Ohlen, Raytheon Information Technology and Scientific Services, EROS Data Center, Sioux Falls, S. Dak.

R.A. McKinley, Raytheon Information Technology and Scientific Services, EROS Data Center, Sioux Falls, S. Dak.

\section{Z. Zhu, USGS, EROS Data Center, Sioux Falls, S. Dak.}

Jim Kitchen, National Park Service, Mesa Verde National Park, Colo.

Landscape variation is driven by many elements, the fire regime of the ecosystem being one of the dominant elements. Variable fire behavior such as variations of intensity and duration, and the resulting patterns of burn severity, strongly influence the species, structure, and composition of the land cover for decades to come. Understanding the fire history of the landscape is an important consideration in any fire or land-management planning processes.

The National Park Service and the U.S. Geological Survey have developed a technique to quickly map burn severity at the landscape scale. The process utilizes temporal analysis of satellite data. Near infrared and short wave infrared bands provide the best contrast between healthy vegetation and burned vegetation. The Landsat Thematic Mapper and Enhanced Thematic Mapper Plus bands 4 (near infrared) and 7 (short wave infrared) are combined in a band ratio transformation called the Normalized Burn Ratio $(\mathrm{NBR}=(\mathrm{B} 4-\mathrm{B} 7) /(\mathrm{B} 4+\mathrm{B} 7))$. NBR transformations are computed for a pre-fire scene and a post-fire scene, which are then subtracted, resulting in the Differenced Normalized Burn Ratio (DNBR). Variations of the DNBR within the fire perimeter are related to variations in burn severity. This process, combined with the 30-year archive of Landsat data, permits the development of a "fire atlas" that reconstructs the fire history of the landscape.

Mesa Verde National Park was selected to prototype a burn-severity atlas. This park is located in southwestern Colorado and is characterized by an arid climate with frequent summer thunderstorms. These summer storms cause many fires and the park experienced major fires in 1959, 1972, 1989, 1996, and 2000. While no Landsat data exist for the 1959 fire, its effect upon the landscape is still clearly visible in the 2000 imagery. Landsat data and the DNBR were used to map burn severity of the fires after 1972. A better understanding of the fire history provides park officials the opportunity to better understand and manage the park's landscape. 


\section{A National Burn-Severity Project: From Concept to Reality}

Carl Key (carl_key@usgs.gov), USGS, Northern Rocky Mountain Science Center, West Glacier, Mont. (406-888-7991)

Nathan Benson (nate_benson@ nps.gov), National Park Service, Everglades National Park, Homestead, Fla. (305-242-7851)

Brian Sorbel (brian_sorbel@nps.gov), National Park Service, Alaska Regional Office, Anchorage, Alaska (907-257-2559)

Zhi-Liang Zhu (zhu@usgs.gov), USGS, EROS Data Center, Sioux Falls, S. Dak. (605-594-6131)

Donald Ohlen (ohlen@usgs.gov), USGS, EROS Data Center, Sioux Falls, S. Dak. (605-594-6026)

Stephen Howard (smhoward@usgs.gov), USGS, EROS Data Center, Sioux Falls, S. Dak. (605-594-6027)

Brian Clement (clementb@usgs.gov), USGS, EROS Data Center, Sioux Falls, S. Dak. (605-594-2713)

In 1999, Key and Benson presented a new remote-sensing measure called the Normalized Burn Ratio and a field sampling protocol called the Composite Burn Index. These acted together as tools for landscape assessment of fire effects, quantifying burn severity over broad regions from 30-meter Landsat data. Various ecosystems were examined to make techniques as transportable as possible. By early 2001, and with support from national leadership in the NPS fire community, we began working with the USGS EROS Data Center on means to produce, archive, and distribute burn mapping and severity assessment for NPS fires across the country. Implementation on this national level ensued throughout the following 2 years. Lessons learned along that path may be relevant to other endeavors in fire science, as research is tested and put into practice. Initially, research precedes implementation and designs in portability and feasibility. A small working group with clearly defined purpose and buy-in from the field is critical. People need to be engaged who understand the problem and who recognize the potential value and usefulness of products. As implementation begins, other important principles emerge: build programs from the field up; maintain relatively small, close-knit core working groups; and be responsive to needs of the field, encouraging their participation in program development. For effective production, distribution, and validation of products, three key elements are important: (1) field personnel geographically distributed to tap local and regional expertise; (2) a centralized facility capable of large-scale production; and (3) continued oversight, coordination, and technology transfer from product developers. As a national program evolves, three final issues prove vital: (1) digital archive and distribution of data and metadata with flexible Web-site design, and access tailored to needs of the field; (2) institutionalized feedback between users and program managers; and (3) continued education about products, potential applications, and what can be gained from product use. 


\section{Post-Fire Characterization of the Land Surface and Vegetation Using Imaging Spectroscopy Data for Cerro Grande NM and Left Hand Creek WY}

Raymond F. Kokaly (raymond@usgs.gov), USGS, Denver, Colo. (303-236-1359)

Barnaby Rockwell (barnabyr@usgs.gov), USGS, Denver, Colo. (303-236-1851)

Laurie Morath (lmorath@usgs.gov), USGS, Denver, Colo. (303-236-5361)

Ralph R. Root (ralph_root@usgs.gov), USGS, Denver, Colo. (303-202-4339)

Susan Goodman (Susan_Goodman@blm.gov), Bureau of Land Management, Denver, Colo. (303-236-4202)

Historically, fire has been among the dominant disturbances in the Rocky Mountain Region of the United States. Recent occurrences of large wildfires, due in part to the increased abundance of fuels resulting from the past century of wildfire suppression, necessitate that resource managers acquire information on the post-fire state of the land surface to plan erosion hazard mitigation strategies and to guide revegetation efforts. This paper reports on the spectroscopic analysis of remotely sensed data collected post-wildfire. Two areas were studied: (1) the May 2000 Cerro Grande fire in Los Alamos, New Mexico, and the Left Hand Creek BLM area in central Wyoming, which has been subject to wildfires in 2000 and 2001. AVIRIS (Airborne Visible InfraRed Imaging Spectrometer) data collected on September 4, 2000, over the Cerro Grande fire site were atmospherically corrected and converted to reflectance by using a single ground calibration site. The spectral signatures in these data were examined in relation to known spectral responses of vegetation, mineral, and post-fire ash materials. The results of this study indicate that the presence of ash-covered surfaces and bare soil/bedrock surfaces can be identified and mapped. Variations in vegetation reflectance arising from chlorophyll and lignin/cellulose absorption features indicate that vegetation within fire perimeters can potentially be discriminated into unburned vegetation, fire-killed nonphotosynthetic needles/leaves, and regenerated vegetation. Hymap imaging spectrometer data over the Left Hand Creek study site were collected on July 2, 2002. In conjunction with the remote-sensing data collection, field measurements of vegetation reflectance and surveys of plant species composition were made for 33 sites within the study area. Measurements of vegetation cover and species composition were made in order to assess the impact of fire on vegetation regeneration in this sagebrush ecosystem. Ongoing efforts in both study areas seek to utilize the post-fire characterization of the land surface in conjunction with in situ studies of erosion and vegetation regrowth to develop predictive models of landscape recovery from wildland and prescribed fires. 


\section{Burn-Severity Patterns in Ponderosa Pine Forests: Implications for Avian Communities}

Natasha B. Kotliar (tasha_kotliar@usgs.gov), USGS, Fort Collins Science Center, Fort Collins, Colo. (970-226-9446)

Sandra Haire, USGS, Fort Collins Science Center, Fort Collins, Colo. (970-226-9446)

Concern that the size and severity of recent fires were "beyond the range of natural variability" in ponderosa pine (Pinus ponderosa) and mixed conifer systems has provided justification for "ecological restoration" programs. However, there are a number of untested assumptions about historic fire regimes and forest structure that affect the validity of the paradigm on which ecological restoration is based. Moreover, it is assumed that specific forest structures will ensure the integrity of natural communities (for example, wildlife). The potential consequences of these assumptions for the ecological integrity of ponderosa pine forests will be discussed, drawing from the results of a study of six burns that occurred in the southern Rocky Mountains and the Colorado Plateau in 2000 and the Hayman fire in 2002. There were striking differences among burns in spatial patterns of burn severity, which correspond, in part, to geography and cover type. Avian responses to burns varied with burn severity and, in some cases, among burns as well. The implications of these results for ecological restoration programs will be discussed.

A first-order model for burning intensities of vegetation and the ignition resistance of structures has been assembled to quantify, in the simplest way, the fire risk posed by nearby vegetation and other structures in the event that wildfire strikes the community. Consideration also is given to the intensity of burning from neighboring structures. The first-order model considers radiative ignition process only. New data from burning structures illustrates the importance of the burning of even small structures to the spread of fires in a community. 


\section{Environmental Implications of Fire-Retardant Chemicals}

Edward E. Little (edward_little@usgs.gov), USGS, Columbia, Mo. (573-876-1817)

Robin Calfee, USGS, Columbia, Mo. (573-876-1817)

Susan Finger, USGS, Columbia, Mo. (573-876-1817)

Each year in the United States, millions of liters of chemicals are used to suppress wildland fires. Since 1995, the Columbia Science Center has been involved in the evaluation of the toxicity of fire-suppressant chemicals to fish and wildlife. In recent studies with long-term retardants, we found that the presence of YPS (sodium ferrocyanide) increases the toxicity of fire retardants. In laboratory and field tests, the toxicity of fire retardants containing YPS significantly increased in the presence of solar ultraviolet radiation and toxic concentrations of cyanide were observed. Fish are capable of avoiding streams containing fire-retardant chemicals. Fire-retardant residues in soil samples obtained from unburned sites in the vicinity of Lake George in the Hayman Reservoir watershed remained toxic for at least 90 days after application; therefore, toxicity of fire retardants may persist in rainwater runoff, particularly from sandy or rocky substrates. Persistence declines with increasing content of organic matter in the soil and cation-exchange capacity. Combustion eliminates the toxicity of the retardant. Other fire-related factors such as ash effluents and high temperatures may cause harmful effects that exceed the effects from chemical toxicity of fire-retardant chemicals. The environmental risk posed by the use of fire-retardant chemicals is event- and site-specific because risk is a function of the toxicity of the substance, the amount applied, persistence in the environment, area treated, and dilution/ mixing ratios of the watershed. 


\section{The Effect of Soil Drainage on the Consumption of Organic Soil Horizons in Boreal Forests}

Kristen L. Manies (kmanies@usgs.gov), USGS, Menlo Park, Calif. (650-329-5010)

Jennifer W. Harden (jharden@ usgs.gov), USGS, Menlo Park, Calif. (650-329-4949)

Boreal forests, which are predicted to be strongly influenced by climate change, contain a significant portion of the world's terrestrial carbon in their surface fuels and organic soil horizons. Fire, the main disturbance of these forests, plays an important role in regulating the exchange of this carbon to and from the atmosphere. One of the main impacts of these fires is the reduction of organic layer thickness, which affects soil temperature, permafrost degradation, decomposition rates, and ecosystem recovery. In addition, the organic material combusted by these fires has a strong impact on the atmosphere through trace gas emissions (for example, $\mathrm{CO}_{2}$ and $\mathrm{CH}_{4}$ ) and smoke aerosols. The amount of organic matter lost to fire is strongly affected by soil drainage. Therefore, we are examining the interactions between fire, soil drainage type, and carbon storage at several locations within Alaska and Canada. At each site, we measured pre- and post-burn thickness, bulk density, and carbon and nitrogen content of the soil organic layer in order to estimate pre- and post-burn $\mathrm{C}$ and $\mathrm{N}$ storage, fuel consumption, emission chemistry, and fire severity. Carbon isotopes also are being utilized to improve estimates of fire severity and evaluate effects of fire on the isotopic composition of atmospheric $\mathrm{CO}_{2}$. Through these data, we hope to provide a better understanding of the impact of fire on carbon storage within the boreal forest, how this impact is influenced by soil drainage class, and how changes in the global climate might effect the carbon cycling within this system. 


\section{Wildland Fire and Post-Burn Effects on Water Quality: A Literature Synthesis and Protocol Development}

Deborah Martin (damartin@usgs.gov), USGS, Boulder, Colo. (303-541-3024)

Sheila Murphy (sfmurphy@usgs.gov), USGS, Boulder, Colo. (303-541-3023)

Tony Ranalli (tranalli@usgs.gov), USGS, Denver, Colo. (303-236-4882)

In 2002, nearly 70,000 fires burned over 6 million acres of land in the United States. Many fires occurred in watersheds that provide drinking water for the public. Fire can cause extensive changes in a watershed, including: burning of vegetation and litter, which releases plant nutrients (such as N, P) and metals (such as $\mathrm{Hg}, \mathrm{Mn}$ ); heating of soils, which alters soil properties and flow paths; and post-fire erosion, which may increase turbidity and sediment loads. These changes can impact water quality; however, the nature and degree of the impact is largely unknown, leaving water managers unprepared to mitigate water-quality impairment.

The USGS is conducting a literature review of research that has reported post-burn effects of fires on water quality of streams, rivers, lakes, or reservoirs. Information about fire behavior (such as area of watershed burned, fire intensity, year and season of fire), watershed characteristics (slope, geology, vegetation), and post-fire water chemistry will be compiled. This compilation will then be analyzed to determine if post-burn water quality can be predicted from a given set of characteristics. The literature review will be submitted to a peer-reviewed journal for publication.

Several other products also will be produced as a result of the literature review. The USGS will host a workshop in Denver, Colorado, in April 2003 to share critical post-fire water-quality information with public water suppliers and Federal, State, and local governmental agencies and to assess data needs of water-quality managers to minimize water-supply impairment. In addition, two databases will be produced. First, the articles used in the literature review will be provided in a searchable Web-based water-quality bibliography. Second, the USGS will create a searchable geospatially based post-fire water-quality database. Our initial ideas include using GeoMAC (Geospatial Multi-Agency Coordination Group) or a similar approach to allow a user to pinpoint an area of interest. Layers such as watershed boundaries, locations of gaging stations, soils, geology, land use, presence of threatened and endangered species, and locations of previous water-quality studies could be activated by the user. These tools could be used by water-supply managers to plan for future impacts of both wildland and prescribed fire. 


\section{Plant Community Response to Crown Fire in Yellowstone National Park}

Eric A. Miller (eric_miller@nps.gov), Wildland Fire, Yellowstone National Park, Wyo. (307-344-2474)

Don G. Despain (don_despain@usgs.gov), USGS, Northern Rocky Mountain Science Center, Bozeman, Mont. (406-994-7257)

Roy A. Renkin (roy_renkin@nps.gov), Yellowstone Center for Resources, Yellowstone National Park, Wyo. (307-344-2161)

Few studies have specifically addressed the long-term response of plant communities to disturbance by crown fire. Most studies consist of one to a few sites and fail to describe succession in the context of soils, slope aspect, elevation, and other differences in environment. We present results from a series of 11 vegetation plots installed between 1977 and 1989 in forests of Yellowstone National Park. Six plots were installed prior to burning and five 1-year post-burn. Two plots reburned in 1988. Ground-layer vegetation and understory and overstory trees were sampled every 1-5 years. Detrended Correspondence Analysis was used to place samples (plot-years) and plant species in the context of environment, and to track the trajectory of individual plots through environmental space over the 13- to 25-year study period. Initial results indicate that magnitude of change in plant community composition is related to burn severity. Pre-fire and early successional plant communities show marked differences related to site environment. The different plant communities appear to behave individualistically, but some trends related to site conditions appear. Recovery of plant species is individualistic and related to reproductive strategy. 


\section{Fuels, Fire Severity, and Invasive Plants: An Example from the Cerro Grande Fire, Los Alamos, New Mexico}

Philip N. Omi (phil@cnr.colostate.edu), WESTFIRE and Colorado State University, Fort Collins, Colo. (970-491-5819)

Erik J. Martinson (erik@cnr.colostate.edu), WESTFIRE and Colorado State University, Fort Collins, Colo. (970-491-1779)

Mohammed A. Kalkhan (mohammed@ nrel.colostate.edu), The Natural Resource Ecology Laboratory and Colorado State University, Fort Collins, Colo. (970-491-5262)

Geneva W. Chong (geneva_Chong@usgs.gov), USGS, Fort Collins Science Center and The Natural Resource Ecology Laboratory, Fort Collins, Colo. (970-491-5835)

Molly Hunter (mhunter@ cnr.colostate.edu), Colorado State University, Fort Collins, Colo. (970-491-0614)

Thomas J. Stohlgren (tom_stohlgren@usgs.gov), USGS, Fort Collins Science Center and The Natural Resource Ecology Laboratory, Fort Collins, Colo. (970-491-1980)

Scant information exists on the efficacy of pre-fire fuel treatments for mitigating wildfire severity. Even less information exists regarding the influence of fuel treatments on second-order fire effects, such as invasive plants. An opportunity to address this research void was provided by the 2000 Cerro Grande fire near Los Alamos, New Mexico. This fire burned over multiple dispersed stands that had previously been treated with a variety of methods, which included thinning with and without slash removal. Immediate post-fire sampling focused on fire-severity comparisons in adjacent treated and untreated stands. Ratings of crown damage and ground char were lower in treated stands than in adjacent untreated stands (paired t-test $p<0.05$ ). We attribute these differences primarily to lower tree density in treated stands $(p<0.05)$. We greatly expanded our sampling effort in the summer of 2001 with a stratified random sampling design and multiscale plots to assess the relations among fuel treatments, stand conditions, fire severity, and invasive plants. Strata included aspect, elevation, cover type, fuel-treatment type, and fire severity. Preliminary results indicate that relative invasive species cover $(\%)$ is higher in ponderosa pine stands compared to other vegetation types sampled, though lower in fuel-treated areas. Relative invasive cover also was highest in severely burned areas and lowest in unburned stands. Further, the invasive threat is lowest in stands that were both thinned and burned. Continuing analyses should greatly improve our understanding of the potential ecological consequences of expanded fuel-treatment activities.

This poster was developed from the paper:

Omi, Philip N., Martinson, Erik J., Kalkhan, Mohammed A., Chong, Geneva W., Hunter, Molly, and Stohlgren, Thomas J., 2002, Fuels, fire severity, and invasive plants within the Cerro Grande fire, Los Alamos, N. Mex., in Engstrom, R.T., and de Groot, W.J., eds., Proceedings of the 22d Tall Timbers Fire Ecology Conference: Fire in Temperate, Boreal, and Montane Ecosystems, Tall Timbers Research Station, Tallahassee, Fla. 


\section{Supporting the Burned Area Emergency Response (BAER) Program with Remotely Sensed Imagery}

Andrew Orlemann (aorlemann@fs.fed.us), USDA Forest Service, Remote Sensing Applications Center, Salt Lake City, Utah (801-975-3769)

In the immediate aftermath of a wildfire, a Forest Service Burned Area Emergency Response (BAER) team is dispatched to the site to do an initial assessment of burn severity and to estimate the likely future downstream impacts due to flooding, landslides, and soil erosion. One of the first tasks for this team is the creation of a burn-severity map that highlights the areas of high, moderate, and low burn severity. This map then serves as a key component in the subsequent flood modeling and Geographic Information System (GIS) analysis. Traditionally, the BAER burn-severity map was created by sketch mapping on a topographic map —or even a forest visitor map-from a helicopter or road-accessible overlook. In 2001, however, Remote Sensing Applications Center (RSAC) established a program to provide remotely sensed satellite imagery to assist Forest Service BAER efforts. To that end, RSAC monitors daily fire activity, tracks satellite acquisition schedules, and acquires the best available post-containment imagery of each fire. RSAC delivers satellite imagery, preliminary burn-severity maps, 3-D visualizations, and hard-copy map products to BAER teams as they arrive at the incident. These items assist the teams in the preparation of rehabilitation and restoration plans. During the 2002 fire season, RSAC supported over 70 BAER teams, mapped 2.6 million acres of burn severity, and provided 80 satellite images. 


\section{Monitoring Wildland Fire Activity at the National Level Using Remotely Sensed} Data

Brad Quayle (bquayle@fs.fed.us), USDA Forest Service Remote Sensing Applications Center (RSAC), Salt Lake City, Utah (801-975-3737)

The USDA Forest Service Remote Sensing Application Center (RSAC), in collaboration with NASA-Goddard Space Flight Center (GSFC) and the University of Maryland, processes Moderate-resolution Imaging Spectroradiometer (MODIS) data to produce active fire map and information products. MODIS-derived fire detections are used to produce active fire maps for the entire United States twice daily. Further geospatial analysis and image processing also is conducted to create associated fire information and image products. The maps and associated products are delivered via the Internet (www.fs.fed.us/eng/rsac/ fire_maps.html) and provide the interagency fire community with a synoptic view of the wildfire situation for the intent of aiding in the strategic allocation of firefighting resources and assets throughout the country as well as provide information for the general public. 


\section{Regulating Post-Fire Surface Erosion: The Relative Efficacy of Reseeding}

Kevin M. Schmidt (kschmidt@usgs.gov), USGS, Menlo Park, Calif. (650-329-5302)

Aided by high winds and drought, the 1988 " 49 'er fire" in the Sierra foothills, northwest of Grass Valley in northern California, burned ponderosa pine and oak trees including tree roots, exposing mineral soil and depositing white ash. To assess subsequent surface erosion on burned hillslopes devoid of vegetation and the effectiveness of a regional aerial reseeding campaign, a 3,890- $\mathrm{m}^{2}$ hollow with an average channel slope of $25^{\circ}$ was observed during the first winter following the fire and revisited 13 years later. Following the fire, one hollow flank was seeded by hand with predominantly Blando brome (Bromus hordeaceus) while the other was not seeded for control. Three sediment traps (one in the channel and one on each flank of the hollow) were installed to estimate erosion rates during the following winter. Seventy $15-\mathrm{cm}$-long spikes, installed with a 7.5-m-grid spacing, provide surface-lowering estimates over a 13-year period. Denudation rates calculated from the sediment traps during the first winter following the fire were distinct with the unseeded, burned slope producing a minimum of 136 tonnes $\mathrm{km}^{-2} \mathrm{yr}^{-1}$ resulting in a surface-lowering rate of $0.12 \mathrm{~mm} \mathrm{yr}^{-1}$. The seeded hillslope, in contrast, produced a modest 62 tonnes $\mathrm{km}^{-2} \mathrm{yr}^{-1}$ and a lowering rate of $0.05 \mathrm{~mm} \mathrm{yr}^{-1}$ corresponding to 55 percent less sediment production. The 55 percent reduction in erosion is a minimum as the sediment trap on the control flank filled between site visits. Using a metal detector to locate the spikes in 2002, measurements of post-fire surface erosion for the entire hollow spanning 13 years reveal a minimum, hollowaverage surface-lowering rate of about $3 \mathrm{~mm} \mathrm{yr}^{-1}$ and a denudation rate of roughly 3,600 tonnes $\mathrm{km}^{-2} \mathrm{yr}^{-1}$. The lowering rate on the seeded flank $\left(3.2 \pm 4.6 \mathrm{~mm} \mathrm{yr}^{-1}\right)$ did not differ from the rate on the control flank $\left(3.7 \pm 3.7 \mathrm{~mm} \mathrm{yr}^{-1}\right)$. Although lowering rates through the first winter after the fire differed markedly between the seeded and native portions of the hollow, the effectiveness of seeding was short-lived with no apparent long-term statistical difference. Surface erosion generally increased downslope with spikes absent from the lower portion of the hillslope. Local areas of aggradation clustered near the top of the hollow. Where the spikes are present, charcoal fragments were found at depths of 0 to $4 \mathrm{~cm}$ within the soil in 2002 . The soil has a soft rupture resistance when dry and a penetration resistance of $0.02 \mathrm{MPa}$. Downslope where the spikes are absent, the soil retains no fire record, has a moderately hard rupture resistance when dry, and a penetration resistance of $0.3 \mathrm{MPa}$. In addition, the decade-scale, post-fire denudation rates exceed catchment-scale rates representative of thousands of years inferred from cosmogenic nuclide concentrations by Riebe and others (2001) for the Sierra Nevada.

Riebe, C.S., Kirchner, J.W., Granger, D.E., and Finkel, R.C., 2001, Strong tectonic and weak climatic control of long-term weathering rates: Geology, v. 29, p. 511-514. 


\section{Hydrologic Recovery of Watersheds in the Los Alamos Area After the Cerro Grande Wildfire, New Mexico}

Jack E. Veenhuis (jeveenhuis@usgs.gov), USGS, Albuquerque, N. Mex. (505-830-7957)

During the past 25 years, three major wildfires have burned large, mostly forested areas on the eastern side of the Jemez Mountains, part of the Rio Grande watershed in north-central New Mexico. In 1977, the La Mesa fire burned 15,270 acres in the Santa Fe National Forest and Bandelier National Monument; in 1996, the Dome fire burned 16,516 acres in the Santa Fe National Forest and Bandelier National Monument. In 2000, the Cerro Grande fire burned 47,650 acres in Bandelier National Monument, the Santa Fe National Forest, Santa Clara Pueblo, San Ildefonso Pueblo, the Los Alamos National Laboratory (LANL), and the City of Los Alamos. A recently published report by Veenhuis (2002) documented the hydrologic effects of the La Mesa fire in Rito de los Frijoles Canyon and the Dome fire in Capulin Canyon; both canyons are located in Bandelier National Monument, which is at the south end of the Cerro Grande fire area. Maximum post-fire flood magnitudes in those two watersheds were about 160 times the magnitudes of the pre-fire annual peak flows immediately following the fires; these flows returned to slightly greater than pre-fire annual peak flows after 3 years.

The aftermath of the Cerro Grande fire caused concern about post-fire flooding, resultant damage to LANL property, and potential mobilization and migration of hazardous LANL material offsite. Structural controls were used in the burned watersheds to mitigate this potential flood damage. These structural controls included aerial seeding, straw mulching, the placement of straw wattles, log silt barriers, rock check dams, contour tilling of the upper layer of burned soil, and contour tree felling.

The timing, nature, and magnitude of the flooding in the burned and unburned watersheds after the Cerro Grande fire have been documented for the subsequent three summer runoff periods. Peak flows at the 32 streamflow stations operated by LANL within and near their boundaries were recorded for the $21 / 2$ summers since the fire.

Watersheds burned in the Cerro Grande fire showed increased peak flows for three summer seasons after the fire. Although the frequency of occurrence of large peak flows increased, these maximum peak flows were not as large per unit of drainage area as in the Rito de los Frijoles and Capulin watersheds. However, the 60-minute maximum rain from Realtime Automated Weather Stations (RAWS) upstream from watersheds gaged by LANL also were not as large as the 60-minute rainfall that occurred after the wildfire in Capulin Canyon, Bandelier National Monument.

Veenhuis, J.E., 2002, Effects of wildfire on the hydrology of Capulin and Rito de Los Frijoles Canyons, Bandelier National Monument, New Mexico: U.S. Geological Survey Water-Resources Investigations Report 02-4152, 39 p. 


\section{Impact of Fire on the Geochemistry of Forest Soils}

Laurel Woodruff (woodruff@usgs.gov), USGS, Mounds View, Minn. (763-783-3291)

William Cannon (wcannon@usgs.gov), USGS, Reston, Va.

Connie Dicken (cdicken@usgs.gov), USGS, Reston, Va.

We are investigating ongoing geochemical effects of fire on the forest floor and mineral soils in an area of the Superior National Forest in northern Minnesota, which was burned in a fuel-reduction prescribed fire by the USDA Forest Service on October 11, 2000. The scheduled fire gave us the opportunity to establish 10 study sites in the proposed burn area. At each site, forest floor material (forest litter, and/or O-horizon) and mineral soil horizons (A-, E-, B- and C-horizons as available) were measured and collected.

On October 13, prior to any post-fire rainfall, we resampled the sites. Burn severity was estimated and, where possible, samples comparable to pre-burn samples were collected. Fire severity was high (100 percent of organic forest floor material consumed, mineral soil exposed) at four sites, moderate at one site (some forest floor material burned, mineral soil not exposed), and light at three sites (surface material charred with minimal loss at the forest floor). Two sites were untouched by fire. The sites were sampled again in May 2001 and May 2002.

Because the footprints of historical fires are apparent in studies of soil geochemistry in both Voyageurs and Isle Royale National Parks (Cannon and others, 2002; Woodruff and Cannon, 2001), it seems apparent that over time severe fire can lead to decreases in carbon and elements bound to carbon from the forest floor. Based on pre-burn analyses and measured thickness and density of organic material and assuming that all mercury in litter and an O-horizon is emitted during high-severity burns, average mercury emissions from this prescribed fire were about $2 \mathrm{~kg} / \mathrm{km}^{2}$. This estimate only takes into account mercury bound to organic material on the forest floor and does not include burned foliage or woody fuels. Immediately after the fire, mercury and carbon contents of A-horizon mineral soils were unchanged, even at sites of high burn severity. However, analyses of A-horizon soils collected in May 2001 show a decrease in carbon but a marked increase in mercury contents. The increase in mercury may be the result of leaching of mercury from the overlying ash layer. One year later, mercury contents in A-horizon soils were lower than the previous May, while carbon contents were little changed. In contrast, lead in A-horizon soils was higher in samples collected immediately after the fire, compared to pre-burn values. Lead contents decreased in both May 2001 and May 2002, although most samples still have higher lead values than pre-burn levels. The increase of lead in soils immediately following the fire may be the result of the concentration of residual lead remaining after the burning of forest vegetation.

References cited:

Cannon, W.F., Woodruff, L.G., Dicken, C.L., and Saari, S., 2002, Prolonged influence of wildfires on the geochemistry of forest soils, Isle Royale National Park, Michigan, and Voyageurs National Park, Minnesota: Geological Society of America Abstracts with Programs, v. 34.

Woodruff, L.G., and Cannon, W.F., 2001, The effect of fire on mercury and carbon in forest soils—Results from northern Michigan and Minnesota: Geological Society of America Abstracts with Programs, v. 33, p. A186. 


\title{
Rocky Mountain Center: An Example of the USDA Forest Service's Fire Consortia for Advanced Modeling of Meteorology and Smoke, FireCAMMS
}

\author{
Karl Zeller (kzeller@fs.fed.us), USDA Forest Service, Rocky Mountain Research Station, Fort Collins, Colo. (970-498-1238)
}

Ned Nikolov (nnikolov@fs.fed.us), USDA Forest Service, Rocky Mountain Research Station, Fort Collins, Colo. (970-295-5980)

John Zachariassen (jzachariassen@fs.fed.us), USDA Forest Service, Rocky Mountain Research Station, Fort Collins, Colo. (970-498-1051)

The Rocky Mountain Center, http://laps.fsl.noaa.gov/usfs/usfs_home.html, is one of five Fire Consortia for Advanced Modeling of Meteorology and Smoke (FireCAMMS) regional cooperative centers for high-resolution simulation modeling. These are in general supported by Forest Service Research under the National Fire Plan that will help firefighters meet fuel reduction and other fire target challenges by providing timely, high-resolution, meteorological data. These centers are in the implementation mode and will:

- Help plan more controlled burns by identifying additional burning windows,

- Help make controlled burns safer relative to escaped fire,

- Help controlled burns to burn cleaner and avoid air-quality problems, and

- Help combat wildfire with relevant weather intelligence.

FireCAMMS will solve problems in fire and smoke management by providing regional simulations of weather and weather-dependent phenomena including fire danger, fire behavior, and smoke distributions. Weather elements such as wind strength and direction, temperature, precipitation, and humidity as well as smoke, fire, and fire-weather indices (Ventilation, Haines, Fosberg, Ketch-Byrum, and so forth) will be simulated with resolutions of 12-km grid spacing (selected areas will nest 4-km grids within them) covering the continental United States. Although each FireCAMMS will maintain a regional focus providing local clients with priority products, all FireCAMMS will produce one or more daily simulations representing hourly changes in all these elements from current conditions to as many as 48 hours of simulated future conditions. FireCAMMS will deliver model simulations to users for application in fire-weather assessments, fire danger, fire behavior, and smoke management.

Initially funded as a research activity within the Forest Service National Fire Plan, FireCAMMS are designed to build broad partnerships among research, fire weather, and air-quality regulatory communities while ultimately transferring better technologies to user communities. At the present time, there are five FireCAMMS in operation, and each is making interim research products available to cooperators, partners, and others interested in high-resolution fire intelligence. Each FireCAMMS will implement new products that can be evaluated immediately, but they also will each carry forward longer term development and research products refined for utility, special regional needs, and reliability.

Currently, the RMC FireCAMMS, with support from the Forecast Systems Laboratory (FSL) of the National Oceanic and Atmospheric Agency, has been displaying "unofficial-research" computer-generated 24-hr specific location fire-weather forecasts for a variety of locations, fires, and so forth, of interest to fire managers in anticipation (and hope) that they be evaluated. These "mesowx" forecasts are updated four times per day and provide the expected hourly weather in specific terms: temperature, relative humidity, windspeed and direction, cloudiness, and precipitation.

For an example,

GOTO: http://laps.fsl.noaa.gov/usfs/usfs_home.html

click on: Rocky Mtn Mesowx Text, then select any location like DADDBENNET, a current prescribed burn in Larimer County, Colorado, and view the 24-hr forecast. (Note that model times are in UTC (universal time coordinates); Mountain Standard Time (MST) is 7 hours behind Greenwich, hence 18:00UTC = 11:00 MST; 00:00 UTC = 5:00 PM or 17:00 MST; 12:00 UTC = 5:00AM MST, and so forth.) 


\title{
Appendix E-White Paper on Pre-Fire Risk Assessment and Fuels Mapping
}

\author{
Jan W. van Wagtendonk, USGS, Western Ecological Research Center
}

Zhi-Liang Zhu, USGS, EROS Data Center

Elizabeth L. Lile, USGS, Rocky Mountain Mapping Center

\section{Issues/Overview}

In recent years, wildland fires and altered fire disturbance regimes have become a significant management and science problem affecting ecosystems and wildland/urban interface across the United States. This white paper describes some of the many pre-fire geospatial needs that should prove useful for conducting effective fire-management programs prior to a fire occurring.

- Remote-sensing mapping and characterization of vegetation and fire-fuels parameters and data sets are required by national fire management and science communities. These needs are clearly defined in strategic documents such as the National Fire Plan (NFP), the Joint Fire Science Program (JFSP), U.S. Congress General Accounting Office (GAO) reports, and the 10-Year Comprehensive Strategy of the USDA Forest Service and DOI. These documents stipulate that there is a consistent need to develop spatial technology and data about fires, fuels characteristics, and burns.

- There is a need for more mapped information on fire fuels within the Nation's wildland areas, particularly those in or near the urban interface, as well as to expand the capability of fire-behavior models such as BEHAVE and FARSITE. In addition, natural resource managers would like to have improved methods for monitoring the outcome of prescribed burns in terms of the objectives of the burn.

- Real-time data are needed in the form of nationwide, seamless, base-layer data (topography, roads, hydrography) integrated with fire data (perimeters, satellite data) to aid in making informed decisions. Geographic Area Coordination Centers (GACCs) are interested in Web-based technology to assist in creating maps for incident support, public briefings, and in prioritizing resource allocation; there is a need to pre-stage data to facilitate data acquisition by incidents.

- There is a need for improved methods of remote estimation of moisture content of wildland fire fuels. Ultimately, satellite-based information that provided real-time estimates of fire-fuel moisture content would be of great benefit to the fire-science community for both improved fire-danger monitoring and inputs to fuel-modeling systems such as BEHAVE and FARSITE.

- There is a need to look at fire-fuels mapping from a broader perspective (that is, beyond mapping vegetation to fit into the traditional fuel model schemes) that lends itself more effectively to state-of-the-art remotesensing capabilities. Two areas of study in this direction might be (1) to compare burn-severity data with the corresponding imagery of the same area before burning to look for correlations between burning and spectral characteristics of the unburned vegetation; and (2) to build fuel characteristics from a combination of spectral characteristics and 3-D vegetation profiles as rendered with multiple return LIDAR (Light Detection And Ranging).

\section{Current USGS Work}

\section{Web-Based Mapping for Fire Applications (GeoMAC)}

Principal investigators:

\author{
Mike Hutt, USGS, Rocky Mountain Mapping Center \\ Elizabeth Lile, USGS, Rocky Mountain Mapping Center \\ Susan Goodman, Bureau of Land Management \\ John Guthrie, USGS, Rocky Mountain Mapping Center
}

The USGS has developed and housed the National Interagency Fire Center's (NIFC) GeoMAC (Geospatial Multi-Agency Coordination Group) site for the past 3 years. GeoMAC is an Internet-based mapping application that allows the public and wildland firefighting coordination centers to access online maps of current wildland fire locations and values at risk using standard Web browsers. This technology provides users with a way to graphically visualize fire-related data that historically have been available only as database files or textual reports. Data layers are collected, processed, and integrated to provide seamless nationwide coverage. Viewing data such as fire location on the landscape and then accessing the associated textual information with a mouse click has vastly 
increased the public's and fire manager's access to data and information. Fire-perimeter data are updated several times a day based upon input from incident intelligence sources: field observation, global positioning system (GPS) data, and infrared (IR) imagery from fixed-wing and satellite platforms. The GeoMAC Web site allows users to manipulate map information displays, zoom in and out to display fire information at various scales and detail, and print hard-copy maps. The fire data are tied to relational databases in which the user can display information on individual fires such as the name of the fire, current burned acreage, and other fire status information.

Potential USGS collaborators: National Interagency Fire Center, Bureau of Land Mangement, USDA Forest Service

\section{The LANDFIRE Project: Developing Critical Spatial Data and Modeling Tools for Implementing the USA National Fire Plan and the Cohesive Strategy}

\author{
Robert E. Keane, USDA Forest Service, Rocky Mountain \\ Research Station
}

Zhi-Liang Zhu, USGS, EROS Data Center

The USDA Forest Service and Department of the Interior developed the National Fire Plan, the 10-Year Comprehensive Strategy, and the recent Implementation Plan to establish a national commitment to restore and maintain ecosystem health in fire-adapted ecosystems for priority areas across the interior West. As a new strategy to map fire risks, a series of maps for the lower 48 States was developed at $1-\mathrm{km}^{2}$ pixel resolution in 2000 that characterized vegetation cover, historical fire regimes, and departures from the historical regimes, known as fire regime condition classes (FRCC). This $1-\mathrm{km}^{2}$ project provided a basis for mapping and assessing fire risk and other valuable data for national prioritization and planning of fire management. It became apparent that finer scale information was critically needed nationally, regionally, and locally to effectively implement the National Fire Plan. In addition, the coarse scale data fell short in addressing fire risk on nonforested lands. The LANDFIRE (LANDscape and FIRE Management Planning System) project, funded jointly by the USDA Forest Service and Department of the Interior, is designed to provide scientifically credible, comprehensive, and critical mid-scale data for prioritization and planning to implement the National Fire Plan, both at the national and local level. Vegetation composition and structure are being mapped at the USGS EROS Data Center, and fuels, FRCC, and a myriad of other maps and tools are being developed at the USDA Forest Service Rocky Mountain Research Station Fire Sciences Laboratory.

Potential USGS collaborators: USDA Forest Service, Department of the Interior, Universities

\section{Greenness Mapping and Fire-Danger Monitoring}

Principal investigators:

\author{
Jeff Eidenshink, USGS, EROS Data Center \\ Jacqueline Klaver, USGS, EROS Data Center \\ Robert Burgan, USDA Forest Service
}

The requirements for analyzing and forecasting wildfire potential at a national scale necessitates that remote-sensing research and applications develop spatial information and technology to assess and forecast fire hazard over large areas. A Fire Potential Index (FPI) was initially developed in 1997 by scientists at the USDA Forest Service in collaboration with the USGS EROS Data Center as an augmentation to standard Forest Service fire-danger indices. The FPI uses both static and dynamic variables from three data sources-fuel type maps, satellite images, and meteorological data-to generate $1-\mathrm{km}$ resolution fire-potential maps for the conterminous United States and Alaska. The FPI enables the local and regional fire planners to quantitatively measure fire-ignition risk. This allows the planners to pre-position the resources in specific geographic areas based on quantitative measurement of the FPI. The feedback from the fire community coupled with recent technological advances has suggested improvements to the FPI model. It is expected that the improvements in the type of meteorological data and the refined relative greenness information will enable the FPI to more accurately determine the influence of weather and climate variability on fire ignition, as well as improved modeling and mapping of dead-fuels moisture content. The ability to assess and provide long-term forecasts of fire hazard with the FPI will provide the USDA and DOI fire managers the use of new remote-sensing technology that is critically required in wildfire prevention.

\section{Potential USGS collaborator: USDA Forest Service}

\section{Fuel and Fire-Hazard Mapping in the Mojave Desert}

Principal investigators:

Matt Brooks, USGS, Western Ecological Research Center

Pat Chavez, USGS, Southwest Geologic Studies Team

Cynthia Wallace, USGS, Southwest Geologic Studies Team

Todd Esque, USGS, Western Ecological Research Center

John Matchett, USGS, Western Ecological Research Center

This project uses existing vegetation, topography, lightning detection, and other spatial data to develop fuel and firehazard models and maps that focus on the Mojave National Preserve area of the Mojave Desert. To develop a fuel map, the existing vegetation map, which consisted of about 20 vegetative-cover categories, was qualitatively classified into categories by relative potential for fire spread and fire 
intensity (high, medium, low) and by fuel models 1 and 6 (the only ones that can be applied to this landscape). Digitalelevation-model data were then used to characterize effect of slope on fire spread rate and intensity. Finally, lightningdetection data (high, medium, low) were incorporated into the model to produce a fire-hazard map. In the future, it is planned to use thematic-mapper images to detect where the interspaces green up the most during spring, as an indication of where most of the interspace fine fuels are. This may allow the identification of areas that will be most sensitive to interannual variation in fuel continuity (for example, from annuals, especially alien annual grasses).

\section{Potential USGS collaborator: National Park Service}

\section{The Use of Thematic Mapper and AVIRIS Data to Map Fuel Characteristic Classes in Western Ecosystems}

\author{
Jan van Wagtendonk, USGS, Western Ecological Research \\ Center \\ Carl Key, USGS, Northern Rocky Mountain Science Center \\ Ralph Root, USGS, Rocky Mountain Mapping Center
}

In order to plan, monitor, and implement fuelsmanagement programs, improved methods of mapping fuels need to be developed. Landsat 7 Thematic Mapper (TM) imagery and Airborne Visible InfraRed Imaging Spectrometer (AVIRIS) hyperspectral data show promise for characterizing the condition of fuels and changes in those conditions over time. The objective of this research, sponsored by the Joint Fire Science Program, is to test the accuracy, efficiency, and cost-effectiveness of AVIRIS and ETM (Enhanced Thematic Mapper) PLUS remotely sensed data for developing fuel characterization classes based on field data collected at five different locations in forest, shrub, and grass ecosystems. Forest fuels and vegetation data necessary for characterizing fuel classes have been collected from more than 1,000 plots in Yosemite National Park. Collection of similar data from more than 360 plots in the Lassen Volcanic National Park has been completed, as has 1 year of data collection from 165 plots in Glacier National Park. Shrub fuels data from Great Basin National Park and grass fuels data from Theodore Roosevelt National Park will extend the analysis to nonforested ecosystems. Data from the plots will be used to establish relations between fuel characteristics and spectral signatures by using spectrum matching and end-member analysis of AVIRIS data. AVIRIS data obtained over Yosemite National Park in September 2001 were updated with a complete reflight in August 2002 to account for sensor malfunctions and cloudcovered areas from the 2001 data. Ground spectrometer data were collected 2 to 3 days after the 2002 flight for purposes of calibration to surface reflectance. Preliminary analysis of a selected portion of the 2001 AVIRIS data indicates the presence of at least 12 to 15 spectral end members, which may correlate to specific fuel models. The existence of 2 years of AVIRIS coverage for from one-third to one-half of the study area offers additional opportunities to study before-and-after fire effects for at least one fire that occurred in the 2002 growing season.

\section{Potential USGS collaborator: National Park Service}

\section{Potential Research and Collaboration}

- Continue working with the National Interagency Fire Center to produce a 5-year project plan for continued GeoMAC (Geospatial Multi-Agency Coordination Group) support. Develop strategies to improve speed and functionality of Web sites. Work closely with the GACC's to refine their requirements and mapping requirements.

- Suggested future research on fusion of fuels identified from electro-optical remote sensing (MSS [Multi-Spectral Scanner] and hyperspectral) with 3-D multiple-return LIDAR (Light Detection And Ranging) profiles to define canopy and subcanopy and possibly estimate vegetation density. USGS and Colorado State University School of Forestry could collaborate on this research.

-Wildland fires present many complex issues that bring with them challenging research needs. USGS remotesensing scientists should conduct studies that are relevant to fire-management issues and compatible with USGS technical capabilities, long-term vision (such as the National Map), and research plans (for example, Geographic Analysis and Monitoring Five-Year Plan).

- Mapping fire fuels requires data and information about vegetation types, structure, and green biomass. How can we design mapping and modeling techniques to measure canopy height, stand size, and understory vegetation in an operational mode? Can we effectively integrate field data with satellite imagery to derive desired variables? Will ecological modeling be effective for deriving vegetation types and structure classes? Will the overall mapping strategy be repeatable? Can remeasured field-plot data drive updating of land and vegetation maps? There also is a critical need to incorporate LIDAR, IFSAR (Interferonmetric Synthetic Aperature Radar) technologies and expertise at EDC to applications of land and vegetation mapping and characterization.

- Improvement in monitoring and forecasting of factors associated with potential fire occurrence. Tools such as Fire Potential Index (FPI) could be improved through studies that lead to a better understanding of (1) vegetation conditions such as moisture content, percent green vegetation, and fuel models; and (2) the effect of climate and weather variability, spatially and temporally, on fire occurrence. 
- Mapping of values at risk. In addition to fuel hazards, there are other factors that contribute to fire risk. In particular, the presence of population centers and access corridors contribute to the potential for a fire to start. Once ignited, values that need protection need to be identified such as communities, structures, watersheds, and sensitive species habitats. A method to categorize, weight, and map these values needs to be developed.

\section{Actions Needed to Improve Pre-Fire Risk Assessment and Fuels Mapping}

Fire-management issues, corresponding to different phases of a fire cycle, require different but related research approaches and technologies. For example, fuel reduction requires mapping of the spatial distribution of vegetation characteristics and fuel models, whereas the monitoring and forecasting of fire-ignition danger primarily depends upon coarse-resolution satellite data and weather models. In addition, the use of accurate fuel models will make fire-danger forecasting more consistent and accurate. The USGS should continue to pursue its efforts in these areas and encourage the involvement of multiple USGS disciplines, other DOI bureaus, and academia.

To accomplish these tasks, the following actions are needed:

- Reaffirm current science relationships with other agencies and bureaus

- Increase USGS fire-science roles in the DOI firemanagement responsibilities

- Develop standard methods and procedures for using satellite imagery and field data for fire-management needs

- Continue developing and investigating Web-based mapping technology for relaying fire information to the public and wildland fire managers

- Convene a fire-science working group within USGS to identify potential research topics and coordinate efforts

- Participate in national and international conferences dealing with remote sensing and fire management 


\title{
Appendix F-White Paper on Post-Fire Effects, Including Physical and Biological
}

\author{
Matt Brooks, USGS, Western Ecological Research Center \\ Susan Cannon, USGS, Landslide Hazards Program \\ Natasha Kotliar, USGS, Fort Collins Science Center
}

\section{Issues/Overview}

Fire can have significant effects on land, water, and air. Fire also can affect humans as exhibited by their responses to the threats posed by fire, and to fire-management activities designed to minimize these threats at the wildland/urban interface. The purpose of this white paper is to summarize the current and potential future scope of USGS fire-effects research, focusing on our particular strengths in the realms of physical, chemical, and biological sciences as applied to terrestrial and aquatic ecosystems and on the social sciences.

\section{Current USGS Fire-Effects Research}

The information presented here was derived from the Science Information System, a July 2002 summary of fire science in the USGS-Biology Western Region compiled by Bob Alverts, an October 2002 USGS-wide email survey, phone interviews, and the personal knowledge of the authors. Our compilation of USGS fire-effects research is undoubtedly incomplete, but it does provide an overview of the range of studies conducted by the USGS. A more comprehensive list of USGS scientists conducting fire research can be viewed at the USGS fire-science Web site (http://firescience.cr.usgs.gov).

\section{Terrestrial Organisms}

\section{Plants}

Effect of fire on plants is perhaps the most common fire research within USGS. Much of the research has focused on fire responses of individual species, especially invasive species, and on post-fire successional patterns and community composition. Some examples of ongoing research include:

- Western coniferous forest response to fire (Craig Allen, Bruce Bury, Jon Keeley, Jennifer Harden, Kristin Manies, Nate Stephenson, Jan van Wagtendonk)

- Blackbrush scrub response to fire (Matt Brooks, Todd Esque, Robert Webb)

- Sagebrush steppe response to fire (Matt Brooks, Steve Knick, Dave Pyke)
- Pinyon juniper response to fire (Craig Allen, Matt Brooks, Todd Esque, Steve Knick, Dave Pyke)

- Hot desert vegetation response to fire (Matt Brooks, Todd Esque, Cecil Schwalbe, Bob Webb)

- Chaparral response to fire (Jon Keeley)

- Wetland vegetation response to fire (Michael Legare)

- Prairie grassland response to fire (Jim Grace, Diane Larsen, Tom Stohlgren)

- Northeastern grassland response to fire (Richard Melecki, Laura Mitchell)

- Florida pineland response to fire (James Snyder)

- Oak savanna response to fire (Ralph Grundel)

- Pacific island vegetation response to fire (Paul Banko, Jim Jacobi)

- Interrelationships between invasive plants and fire (Jayne Belnap, Matt Brooks, Todd Esque, David Fellows, Jim Grace, Jon Keeley, Steve Knick, Robert Mitchell, Dave Pyke, Tom Stohlgren)

\section{Soil Flora and Fauna}

- Effects of fire on microphytic crusts (Jayne Belnap, Jeanne Ponzetti)

\section{Animals}

Studies of the effects of fire on wildlife cover a broad range of taxa and a variety of ecosystems. Many studies of wildlife are indirectly related to fire because of the influence of fire on vegetation and ecosystem structure and dynamics. Numerous studies, however, are explicitly investigating the effects of fire and fire management on wildlife species. Some studies are limited to either wildland fire or prescribed fire, whereas a few studies compare both. Here we highlight examples of ongoing research:

- Effects of burn severity and spatial variation in burnseverity patterns on avian communities in forested systems of the Rocky Mountains (Natasha Kotliar)

- Effects of wildland fire on wintering grassland birds in Arizona (Janet Ruth) 
- Effects of wildland fire on caribou within Alaska's boreal forest ecosystem (Layne Adams, Kyle Joly)

- Effects of wildland fire on rare and endangered species, including the red-legged frog, the Point Reyes jumping mouse, and Myrtle's silverspot butterfly at Point Reyes National Seashore (Gary Fellers)

- Effects of fire on long-lived species (for example, desert tortoises), the role of rodents in the restoration of plant species after fires, and how fire and plant invasions affect the diversity and abundance of terrestrial invertebrates, rodents, reptiles, and birds (Todd Esque)

- Effects of prescribed fire on terrestrial salamanders (Robin Elizabeth Jung)

- Effects of prescribed fire on Florida panthers (Joseph Clark)

- Effects of prescribed fire on breeding bird populations in longleaf pine ecosystems (James Grand)

- Effects of prescribed fire on abundance and reproductive success of nongame birds in Southwestern forests (Courtney Conway)

- Effects of prescribed fire on avian communities in ponderosa pine forests across the Western United States (Natasha Kotliar)

- Comparison of the effects of wildland and prescribed fire on habitat quality (availability of downed woody debris) for terrestrial and stream herpetofauna in the Pacific Northwest (Bruce Bury)

- Comparison of the effects of wildland and prescribed fire on avian communities in ponderosa pine forests of the Colorado Front Range (Natasha Kotliar)

\section{Aquatic Organisms}

\section{Plants and Animals}

- Comparison of the ecosystem properties of boreal coniferous forest that has been burned by prescribed understory fire, burned by stand replacement wildfire, and forest that has not been burned. Response variables include amphibians, aquatic macroinvertebrates, periphyton, and stream conditions (Bruce Bury, Steve Corn)

\section{Atmospheric Response}

- Effects on carbon cycling, nutrients, and atmospheric emissions of fires in interior Alaska (Jennifer Harden, Kristen Maines).

\section{Chemical Response}

- Examination of the effect of fire on the mobility, transport, and bioavailability of environmentally important metals using comparisons of pre- and post-wildfire stream-sediment and stream-water geochemistry in Idaho (Robert Eppinger, Paul Briggs, Karen Lund) and Alaska (Larry Gough, Rich Wanty, Bronwen Wanty, James Crock); analyses of rainwater and lung fluid leachates from fire ash in Colorado (Geoff Plumlee) and soil chemistry in the Northeast (Bill Cannon and Laurel Woodruff). Epidemiological evaluation of the potential spread of environmentally sensitive compounds after fire (Geoff Plumlee)

- Characterization of the environmental implications of forest-firefighting chemicals (Susan Finger, Ed Little, Craig Johnson)

- Evaluation of the effects of carbon cycling through examination of the interactions between soil drainage, fire, and carbon storage in interior Alaska (Jennifer Harden, Kristen Maines)

- Evaluation of the effects of post-fire runoff (both water and sediment) on water quality (Deborah Martin, Geoff Plumlee)

\section{Physical Response}

- USGS scientists are evaluating the potential for runoff, erosion, and sedimentation response of burned watersheds. Data from numerous field experiments and mapping and monitoring efforts in burned watersheds throughout the Western United States are being used to develop quantitative tools and methodologies for predicting both the magnitude and probability of postfire flooding, sedimentation, and debris-flow events (Sue Cannon, John Elliott, Bob Jarrett, Deborah Martin, John Moody, Chuck Parrett, Ken Pierce, Kevin Schmidt, Janet Slate, Jack Veenhuis)

- Scientists are providing instrumentation for post-fire early warning systems and performing assessments of post-fire hazards (Mark Anderson, Sue Cannon, Catherine Costello, John Elliott, David Grey, Bob Jarrett, Ralph Teller, Al Rea, Mark Smith)

\section{Linkages Between Fire Effects on Biotic and Abiotic Ecosystem Components}

USGS scientists have developed tools that provide invaluable baseline information to scientists working over a broad spectrum of studies of burned area response. 
- Methods to characterize burn severity using remotely sensed data provide a spatially consistent and replicable data set (Nate Benson, Carl Key, Don Ohlen, Zhi-Liang Zhu)

- Techniques to use remotely sensed imaging spectroscopy to characterize the distribution of post-fire vegetation, mineral, and ash materials provide important baseline data to research scientists (Ray Kokaly, Barnaby Rockwell, Laurie Morath, Ralph Root)

- A project funded by the USGS Venture Capital fund provides an example of integrated, multidisciplinary science. The scope of the project, titled "The Ecological, Hydrological, and Geological Consequences of Burn Severity and Social Applications of These Results," crosses the terrestrial and aquatic ecosystems boundary, and links the fields of chemical, biological, and physical response (Sue Cannon, Geneva Chong, Sandra Haire, Carl Key, Ray Kokaly, Natasha Kotliar, Deborah Martin, John Moody, Jonathan Taylor)

\section{Social Issues}

The social effects of fire on humans at the wildland/urban interface are of increasing concern for land managers. A group of USGS social scientists (Jonathan Taylor, John Hogan) have been involved with the following different projects that are related to the implications of fire in the ever-increasing wildland/urban interface.

- Working with "survivors" of the Cerro Grande (N. Mex.) and the Green Knoll (Wyo.) burns to determine: (1) knowledge and implementation of fire risk, and (2) effective communication at the time of the fire event

- Collaborative research with other USGS researchers to develop effective public education instruments for information dissemination to communities at risk of fire. This includes the effects of fire of different burn severities. Public groups with fire experience will help develop communication tools for other communities in the wildland/urban interface

Information on research described in this section can be accessed online at http://cris.csrees.usda.gov/star/brd.html

\section{Potential Research and Collaboration}

Develop closer collaborations with land managers in conducting and evaluating the effects of prescribed fires.-The focus of the National Fire Plan on fuels treatments and fire restoration points to the need to evaluate the physical, chemical, and atmospheric impacts of prescribed burning. In addition, fire effects are strongly influenced by environmental conditions before, during, and after fires; yet most fire research does not include all three of these temporal phases. Much of what is known about fire effects at landscape scales comes from post-hoc studies, which do not allow for detailed descriptions of the conditions that produced the observed fire effects. Prescribed fires conducted for fuels reduction or resource benefits offer important opportunities to develop well-replicated and documented studies on a wide range that would be nearly impossible for scientists to implement as purely experimental research burns.

Develop the "rapid response" capability to study fire effects during and immediately after wildfires.-Utilize wildfires as opportunities to collect fire-effects information and to validate the information derived from prescribed fires and post-hoc studies of wildfires.

Participate on Burned Area Emergency Response (BAER) projects.-Participation will allow scientists to opportunistically collect fire-effects data and will help them develop and further solidify relationships with land managers that could lead to future fire-effects research opportunities.

Improve collaborations with USDA Forest Service fire scientists.-Through better collaboration, the USGS and USDA Forest Service could improve their abilities to deliver effective fire-science tools to land managers. Even in the absence of a coherent fire-science program, USGS scientists have already established strong collaborations with personnel from the NPS, BLM, BIA, NRCS, NWS, USBR, State Geological Surveys, State and County Offices of Emergency Services, and numerous universities. However, the USGS and USDA Forest Service uniquely share the common purpose of providing science support for agencies in the DOI and USDA, and we feel that the quality of science produced by the two science agencies would be greatly improved through the development of additional collaborative efforts.

Improve links between pre-fire risk assessment/fuels mapping, fire-effects research, and post-fire rehabilitation/ restoration.-The USGS has scientists with strong capabilities in each of these three research areas. By explicitly linking these areas of research, more powerful fire-management tools can be developed.

\section{Actions Needed to Improve USGS Post-Fire Research}

The capability to conduct integrated research is a hallmark of the USGS, which should be applied to the study of fire effects. Individually, the various disciplines and research groups within USGS have the expertise and ability to address specific physical or biological research questions, but poor integration and communication between them hinders their ability to address more complex interdisciplinary questions. Poor integration is in part due to inadequate funding. A truly 


\section{Third U.S. Geological Survey Wildland Fire-Science Workshop}

integrated, multidisciplinary program requires considerable funding and substantial resources. A strong leadership commitment is necessary to achieve the potential of such a program. Specific actions include the following:

1. Establish a Fire Science Program that is well and consistently funded.

2. Provide funding for the establishment of interdisciplinary research teams to focus on high priority DOI fire research needs, especially those that necessitate the integrated study of pre-fire hazard assessments, fire effects, and post-fire restoration. Potentially direct place-based funding to accomplish this goal.

3. Promote collaborations between USGS and USDA Forest Service fire scientists to address significant cross-cutting research issues common to the DOI and USDA agencies.

4. Increase communication among USGS researchers, collaborators, and end-users through up-to-date Web pages and conferences focused on sharing scientific advances and management tools. 


\title{
Appendix G-White Paper on Rehabilitation and Restoration
}

\author{
David A. Pyke, Rangeland Ecologist, USGS, Forest and Rangeland Ecosystem Science Center \\ Randy A. McKinley, Senior Scientist, USGS, EROS Data Center
}

\section{Issues/Overview}

The need for increased fire research is a major issue facing science agencies including the U.S. Geological Survey (USGS) (Zhu and Knick, 2002). In this paper, we briefly describe examples of current USGS research on rehabilitation and restoration conducted after wildland fires, suggest potential research and collaboration opportunities related to rehabilitation and restoration, and describe actions that could be taken by the USGS to improve our fire-science rehabilitation and restoration activities.

For this paper, we define restoration and rehabilitation as the intentional manipulation of physical or biological processes of an ecosystem to achieve historical conditions or to reduce negative effects of wildland fire. Restoration of natural fire regimes into ecosystems where fire has been removed also is included in this topic. Additionally, we address aspects of mapping and monitoring wildland fire effects where the intent is to identify candidate areas for rehabilitation and restoration, monitor the long-term success of rehabilitation and restoration efforts in reducing post-fire effects, or monitor post-fire effects where no rehabilitation or restoration has occurred. We provide information on projects that address the full range of spatial and temporal scales.

\section{Current USGS Work}

Wildfires are natural components of nearly all ecosystems; however, the size, intensity, and frequency of these fires change because disturbances, including fire suppression, have led to alterations in ecosystem processes. In many ecosystems, fire suppression has led to changes in plant species dominance, buildup of fuels, and in some cases to the encroachment of plant growth forms into adjacent ecosystems that recently lacked that growth form (Keeley and Stephenson, 2000; Keeley, 2001). Conversely, shifts in the dominance of plant species life forms, the change from perennial to annual life forms, in other ecosystems cause fires to burn more frequently than in the past (Brooks and Pyke, 2001).

Although fire-dependent ecosystems may require periodic burning to maintain ecosystem processes and stimulate plant regeneration, some wildfires may place ecosystems at greater risk of degradation. Topographic position, nearness to human populations, or existing invasive plants may create greater challenges for land managers to reduce post-fire effects. Rehabilitation or restoration of physical or biological ecosystem processes is typically initiated when a site is threatened either by soil erosion or by spread of invasive species. Federal funding for wildfire rehabilitation or stabilization of lands requires that certain criteria be met before funds will be awarded. Physical stabilization is necessary when protection of human life, property, and critical cultural and natural resources are threatened by erosion or landslides or to prevent further degradation to affected resources by wind or water erosion or to repair damages caused by fire-suppression operations. Rehabilitation is conducted to repair or improve land damaged by fires and unlikely to recover naturally to its pre-fire ecosystem structure, function, diversity, and dynamics, or to restore healthy stable ecosystems even if these rehabilitated ecosystems cannot fully emulate historical conditions (see http://fire.r9. fws.gov/ifcc/Esr/handbook). USGS activities related to fire rehabilitation and restoration are listed in table 1 by scientist name. Collaborations as of October 2002 also are listed.

Restoring natural fire cycles. - Forested ecosystems in the Western United States have undergone considerable changes in fire history in the last 100 to 150 years. Some of these changes may be direct results of fire suppression, but climatic changes also may influence some of these changes. Stephenson and others (table 1) are using dendrochronology, paleoecology, current vegetation distributions, and models with forest structure, environment, and fire to aid in illustrating past and current fire regimes in the Sierra Nevada, Olympic, Northern Rocky, and Colorado Rocky Mountains. Similar work has been done in mountain big sagebrush communities where western juniper is encroaching (Miller and Tausch, 2001). These scientists hope to draw general conclusions regarding current and past fire regimes that may assist in designing fire-management plans for these ecosystems.

In western forests and coastal plains, fire has been suppressed. Keeley and others (table 1) are conducting studies to examine historical fire regimes in grassland, shrubland, and forestland ecosystems within California. As indicated in table 1, Keeley and others in California, James Grace and others in Texas, and Susan Grace and others in southern forests are examining techniques for restoring fire to systems where it has been eliminated. These studies should provide managers with techniques for safely reintroducing fire into the management of these ecosystems. 
Table 1. Summary of activities of USGS scientists involved in the study of post-fire rehabilitation and restoration.

[Information was derived from the U.S. Geological Survey Fire Science Directory (Grace, 2001)'1, an October 2002 U.S. Geological Survey-wide email survey, and personal contacts by the authors (October 2002)]

\begin{tabular}{|c|c|c|}
\hline Name(s) of scientists ${ }^{2}$ & Activity description & Collaborators $^{3}$ \\
\hline $\begin{array}{l}\text { Terence P. Boyle, Robert Waltermire, } \\
\text { Raymond Watts }\end{array}$ & $\begin{array}{l}\text { Planning for forest fire remediation using } \\
\text { Geographical Information Systems. }\end{array}$ & USGS-Geography, USGS-Biology \\
\hline James Grace and Susan Grace & Prescribed fire for habitat restoration. & $\begin{array}{l}\text { Southeast Missouri St. University, Louisiana } \\
\text { State University, Johnson Controls, FWS }\end{array}$ \\
\hline Robert Gresswell & $\begin{array}{l}\text { Effects of fire on aquatic systems. Rehabilitation } \\
\text { of animal (fish) populations after fire. }\end{array}$ & $\begin{array}{l}\text { BLM, USDA Forest Service, Oregon State } \\
\text { University }\end{array}$ \\
\hline James Jacobi, Paul Banko, others & $\begin{array}{l}\text { Fire ecology on islands, alien fuels, fire, and } \\
\text { endangered species restoration. }\end{array}$ & $\begin{array}{c}\text { Initiating efforts at this time, but expect NPS, } \\
\text { DOD, FWS, TNC, Private, USDA Forest } \\
\text { Service, Department of Fish and Wildlife }\end{array}$ \\
\hline Jon Keeley & Fire in Western ecosystems. & $\begin{array}{l}\text { University of Arizona, Duke University, } \\
\text { Montana State University, University } \\
\text { of California San Diego/Berkeley }\end{array}$ \\
\hline Carl Key & Remote-sensing fire effects, fire history/ecology. & NPS, USGS-Geography, USDA Forest Service \\
\hline Steve Knick & Role of fire in shrub/steppe ecosystems. & $\begin{array}{l}\text { BLM, USDA Forest Service, Oregon State } \\
\text { University }\end{array}$ \\
\hline Raymond Kokaly, others & $\begin{array}{l}\text { Remote sensing and imaging spectroscopy to map } \\
\text { fire severity, erosion potential, and vegetation } \\
\text { recovery after wildfires. }\end{array}$ & NPS, USDA Forest Service \\
\hline Nathan Stephenson & Restoration of natural fire regimes. & $\begin{array}{l}\text { University of Arizona, Duke University, } \\
\text { Montana State University, University of } \\
\text { California San Diego }\end{array}$ \\
\hline $\begin{array}{l}\text { Zhi-Liang Zhu, Donald Ohlen, } \\
\text { Stephen Howard, Randy McKinley, } \\
\text { others. }\end{array}$ & $\begin{array}{l}\text { Mapping burns using satellite imagery for long- } \\
\text { term monitoring and immediate post-fire BAER } \\
\text { applications. }\end{array}$ & $\begin{array}{l}\text { NPS, BLM, NIFC, BIA, USDA Forest Service, } \\
\text { others }\end{array}$ \\
\hline
\end{tabular}

${ }^{1}$ See http://firescience.cr.usgs.gov/html/FireScienceDirectory.html

${ }^{2}$ The location and contact information for USGS scientists can be found at http://www.usgs.gov/bio/USGS/ph.html

${ }^{3}$ See front of report for listing of abbreviations and acronyms. 
Stabilization.-To our knowledge, no USGS projects are examining any aspect of emergency stabilization projects. Several projects have examined sedimentation of streams following fires, but these were addressed in the post-fire effects white paper in this volume. The BLM has provided some sediment monitoring data in Arizona associated with the research by Esque and others (table 1).

Rehabilitation and restoration of ecosystems.Biological studies on restoration and rehabilitation are generally being conducted in the Great Basin, Mojave Desert, and the Colorado Plateau. Studies range from investigations of ecosystem processes before and after restoration to collaborative work in evaluating management-agency rehabilitation techniques. Most of these studies focus on revegetation after fire.

To our knowledge, only one project has proposed rehabilitation or restoration of an animal species after wildfire: the former Intermountain Greenstripping and Rehabilitation Research Project (BLM/National Biological Survey/USGS) that evolved into the Coordinated Intermountain Restoration Project (CIRP). The goals of this new project are to: (1) understand ecological responses to disturbances and invasive plants; (2) develop strategies and appropriate techniques to maintain or restore functioning ecosystems; and (3) demonstrate and transfer scientific results and applications. Current projects are being conducted by Pyke and others (table 1). Individual studies are examining the microbial diversity and decomposition of plant litter in locations dominated by exotic annual grasses and those dominated by native sagebrush grasslands, defoliation of cheatgrass as a mechanism to reduce cheatgrass populations in preparation for restoration, fire and herbicide effects on cheatgrass and on native plants for restoration, and sagebrush seedling establishment in BLM wildfire rehabilitation projects.

Funds from CIRP are leveraging a four-State, USDAfunded project on restoration and rehabilitation of lands dominated by exotic annual grasses. Pyke and others are conducting studies to evaluate establishment of 21 accessions of native grasses with and without cheatgrass competition. The native grasses will be compared to crested wheatgrass, an introduced perennial grass used successfully in rehabilitation projects where cheatgrass competition will likely occur. Because competition by cheatgrass often limits establishment success of rehabilitation species, studies will examine the role of nitrogen in cheatgrass competition with native grasses. Results of these studies may lead to rehabilitation strategies that involve reductions in nitrogen availability during the establishment phase of the native plants.

Soil nitrogen and phosphorus are two nutrients whose availability may increase or decrease depending on fire intensity. Brooks, Belnap, Keeley, and others (table 1) are conducting a Joint Fire Science Program research project to determine soil temperatures necessary to reduce or increase these nutrients. If prescribed fires can burn at appropriate temperatures to encourage restoration of native plants and biological soil crusts while retarding the expansion of invasive plants, then managers would be able to use fire as a tool for restoring native plants and soil processes.

Esque and others (table 1) are conducting a number of cooperative rehabilitation projects. In the BLM Arizona Strip, a fire-rehabilitation project is using replicated treated and untreated areas to examine the effectiveness of various seeding treatments on plant establishment and diversity.

The use of native plants in BLM fire-rehabilitation projects and the implementation of monitoring to determine the effectiveness of rehabilitation projects is being examined by Pyke and others (table 1). Over 11 years, an average of five species are planted in rehabilitation projects, but only one to two of the species are native.

Rehabilitation of animal populations is rarely conducted after fires because animals are generally capable of moving to locations with suitable habitat. One exception is fish. Gresswell (1999) suggests that endangered fish might need rehabilitation in burned watersheds if the threat of sedimentation after fire would threaten their survival. Managers might consider trapping and moving fish to unburned watersheds for several years until the habitat in the burned watershed improves. After rehabilitation, fish could be returned to the original stream.

Zhu and Key (table 1) use satellite imagery to map and monitor wildland fire effects, including burn severity, in a cooperative project with the NPS. In part, these assessments develop baselines for long-term ecological monitoring, with the intent of assessing the success of rehabilitation and restoration efforts in reducing post-fire effects or monitoring post-fire effects where no rehabilitation or restoration has occurred. One significant result of the USGS/NPS cooperative effort has been the development of a Web site providing online access (http://edc2.usgs.gov/fsp/severity/fire_main.asp) to a growing archive (over 65 fires) of burn severity and other fire information. Originally dedicated to NPS fires, this Web site now supports fires on other DOI-managed lands as well. Zhu, Key, and others (table 1), in cooperation with NPS, BLM, Bureau of Indian Affairs, and others, have used satellite imagery to map burn severity and fire perimeters in response to BAER needs where the intent is to contribute to the immediate post-fire identification of areas potentially requiring rehabilitation or restoration. Hutt and others (table 1), in cooperation with FEMA, USGS-Water, and the State of Colorado, have integrated burn-severity data with various other GIS-based data layers to generate maps that assist in the delineation of potential post-fire hazards and risks and assist in identifying areas potentially requiring rehabilitation and stabilization. 


\section{Potential Research and Collaboration}

The following research topics or apparent information gaps within the area of rehabilitation and restoration may be compatible with USGS expertise and suitable for increased USGS attention and focus.

- Landscape approach to restoration planning.-Total restoration of regional areas is not possible within short timeframes because personnel and logistical constraints permit only a collection of local efforts. Consequently, restoration planning should be based on a hierarchical approach in which general land-use decisions and analyses for larger regions are complemented with sitespecific actions based on specific variables. A multiscale approach is needed for prioritizing restoration activities based on a spatial assessment of environmental variables and would include the use of risk-assessment models, fuels-management and fire-rehabilitation activities, and work proposed by the BLM's Great Basin Restoration Initiative.

- Effectiveness of sediment reduction treatments.When watersheds are threatened by sediment movement and landslides, combinations of physical barriers (sediment traps) and revegetation are often used to reduce these threats. Although some research and monitoring studies have examined the success in revegetation techniques, few have examined the success of physical barriers or revegetation on the erosion and stream-sediment transport, especially in semiarid ecosystems. Erosion is one of the two major areas where additional funding for fire rehabilitation is available to land managers; therefore, it seems reasonable that research and monitoring of the effectiveness of these programs are needed.

- Use exclusion after fires and fire rehabilitation.Land managers currently restrict or eliminate uses (livestock grazing or recreation) on areas burned or rehabilitated for 3 to 5 years or until, in their professional judgment, the resources can tolerate these uses. Recent attempts to document the scientific basis for these restrictions in ecosystems have been unsuccessful. Land-management agencies would like experiments on the length of time and the plant and soil evidence necessary to provide indications of when land uses can be resumed on burned and rehabilitated lands.

- Determining the effect of no rehabilitation treatments.Most monitoring is done on areas where rehabilitation treatments are implemented, yet untreated areas are often not examined. To determine the community resilience after fires, untreated areas need to be studied to determine the effect of no rehabilitation treatment on lands.

- Standardization monitoring protocols and databases.Monitoring of rehabilitation projects is only done on a small proportion of rehabilitation projects. However, monitoring projects rarely use the same protocols, making comparisons of results difficult. Collaboration between research and management agencies is needed to provide standardized protocols for monitoring firerehabilitation designated projects. Along with a standardized protocol, results should appear in a standardized database. This database would allow managers and scientists to determine which techniques are successful in different environments.

- Burn mapping/monitoring.-The ability of USGS to provide satellite burn mapping services across DOI managed lands should be encouraged. Results from rapid response (immediate post-fire) and long-term burn mapping/monitoring activities should be available across agencies (preferably online) and archived in a centralized location(s) in standardized formats. This work should be closely linked to rehabilitation needs, sedimentation, or invasion risks to aid in planning postfire rehabilitation or restoration of ecosystems.

- Breakout group suggested topics.-The following topics or issues were suggested as potential research areas for new or expanded USGS involvement:

- Expanded research related to determining fire history

- Additional research to determine what needs restoration. What actions are needed and where are actions appropriate? What is the desired end-point and the economical and ecological feasibility? Is end-point acceptable to society?

- Expanded research exploring the use of fire as a tool for restoration

- Research on the concept of using salvage logging as a rehabilitation technique

- Study of the applicability of rehabilitation techniques used in forest ecosystems to nonforest ecosystems

- Research competition among native, invasive, and introduced species

- Fire Effects Information System (FEIS) updates for rangeland species

- Further research on hillslope and channel erosion

- Research to establish watershed-level comparisons for rehabilitation techniques (for example, Fire/Fire Surrogate) 


\section{Needed Actions to Improve Rehabilitation and Restoration Research}

Actions for USGS research on rehabilitation and restoration to improve USGS fire science, internal collaboration, and external partnerships are listed in table 2 .

Table 2. Proposed rehabilitation and restoration actions to improve USGS fire science, internal collaboration, and external partnerships.

\begin{tabular}{|c|c|}
\hline Topic & Specific actions \\
\hline Fire science & $\begin{array}{l}\text { - Inventory and map risk of invasive } \\
\text { species spread with wildfires } \\
\text { - Pursue use of satellite imagery and other } \\
\text { remotely sensed data to map and monitor } \\
\text { response to rehabilitation and restora- } \\
\text { tion activities, monitor burn areas not } \\
\text { rehabilitated, and assess performance of } \\
\text { prescribed fire } \\
\text { - Rehabilitation hydrology, runoff, soil } \\
\text { erosion, sedimentation, and landslide } \\
\text { risk } \\
\text { - Develop post-fire protocol to determine } \\
\text { need for rehabilitation } \\
\text { - Pursue a standard protocol for fire } \\
\text { rehabilitation and restoration monitor- } \\
\text { ing with a database that can be queried } \\
\text { online } \\
\text { - Determine necessary use exclusion } \\
\text { periods after wildfires } \\
\text { - Determine native plant accessions and } \\
\text { establishment techniques that allow na- } \\
\text { tive plants to successfully compete with } \\
\text { invasive plants }\end{array}$ \\
\hline Internal collaboration & $\begin{array}{l}\text { - Improve communication among USGS } \\
\text { researchers working in common areas } \\
\text { through periodic teleconferences, meet- } \\
\text { ings, newsletters, and so forth } \\
\text { - Establish a wildland fire rehabilitation } \\
\text { and restoration interdisciplinary team } \\
\text { - Develop a Web-based database for reha- } \\
\text { bilitation and restoration monitoring data }\end{array}$ \\
\hline External partnerships & $\begin{array}{l}\text { Build stronger working relationships } \\
\text { with other DOI resource managers } \\
\text { and research scientists working in the } \\
\text { rehabilitation and restoration area by } \\
\text { attending non-USGS meetings, confer- } \\
\text { ences, and so forth }\end{array}$ \\
\hline
\end{tabular}

Table 2.-Continued.

\begin{tabular}{|c|c|}
\hline Topic & Specific actions \\
\hline $\begin{array}{l}\text { External partnerships- } \\
\text { Continued }\end{array}$ & $\begin{array}{l}\text { Proactively contact non-USGS } \\
\text { staff and facilities for possible } \\
\text { collaboration } \\
\text { - Provide real-time fire and burn } \\
\text { information on Web-based inter- } \\
\text { faces (for example, GeoMAC, } \\
\text { NPS/USGS National Burn } \\
\text { Mapping Project) that link data } \\
\text { producers with users (that is, DOI } \\
\text { BAER teams and land managers) } \\
\text { concerned with rehabilitation and } \\
\text { restoration } \\
\text { Develop, and share externally, } \\
\text { standardized databases for long- } \\
\text { term archiving of fire rehabilita- } \\
\text { tion and restoration-related records } \\
\text { - Encourage USGS to take a } \\
\text { stronger role or lead in developing } \\
\text { interagency monitoring protocol } \\
\text { Encourage USGS to expand inter- } \\
\text { larger organizations, international } \\
\text { organizations, and so forth }\end{array}$ \\
\hline
\end{tabular}

\section{References}

Brooks, M.L., and Pyke, D.A., 2001, Invasive plants and fire in the deserts of North America, in Galley, K.E.M., and Wilson, T.P., eds., Proceedings of the Invasive Species Workshop-The Role of Fire in the Spread and Control of Invasive Species: Fire Conference 2000, The First National Congress on Fire Ecology, Prevention, and Management, Miscellaneous Publication 11, Tall Timbers Research Station, Tallahassee, Fla., p. 1-4.

Gresswell, R.E., 1999, Fire and aquatic ecosystems in forested biomes of North America: Transactions of the American Fisheries Society, v. 128, p. 193-221.

Keeley, J.E., 2001, Fire and invasives in mediterranean-climate ecosystems of California, in Galley, K.E.M., and Wilson, T.P., eds., Proceedings of the Invasive Species WorkshopThe Role of Fire in the Spread and Control of Invasive Species: Fire Conference 2000, The First National Congress on Fire Ecology, Prevention, and Management, Miscellaneous Publication 11, Tall Timbers Research Station, Tallahassee, Fla., p. 81-94. 
Keeley, J.E., and Stephenson, N.L., 2000, Restoring natural fire regimes in the Sierra Nevada in an era of global change, in Cole, D.N., McCool, S.F., and O'Loughlin, J., eds., Wilderness Science in a Time of Change Conference: RMRS-P-15, v. 5, USDA Forest Service, Rocky Mountain Research Station, p. 255-265.

McPherson, G.R., 2001, Invasive plants and fire-Integrating science and management, in Proceedings of the Invasive Species Workshop-The Role of Fire in the Spread and Control of Invasive Species: November 27-December 1, 2002, San Diego, Calif., Tall Timbers Research Station, Miscellaneous Publication 11, Allen Press, Inc., Lawrence, Kan., 146 p.
Miller, R.F., and Tausch, R.J., 2001, The role of fire in juniper and pinyon woodlands - A descriptive analysis, in Galley, K.E.M., and Wilson, T.P., eds., Proceedings of the Invasive Species Workshop-The Role of Fire in the Spread and Control of Invasive Species: Fire Conference 2000, The First National Congress on Fire Ecology, Prevention, and Management, Miscellaneous Publication 11, Tall Timbers Research Station, Tallahassee, Fla.

Zhu, Z., and Knick, S., 2002, Integrating fire science in BRD and NMD_Needs and opportunities: June 2002, U.S. Geological Survey workshop, USGS EROS Data Center, S. Dak. 


\title{
Appendix H-White Paper on a USGS Fire Response Plan
}

\author{
Deborah Martin, Research Hydrologist, USGS, National Research Program \\ Mike Hutt, Cartographer, USGS, Rocky Mountain Mapping Center \\ Tom DiNardo, Cartographer, USGS, Rocky Mountain Mapping Center
}

\section{Acknowledgments}

The authors would like to thank Susan Grace, USFWS, for her contributions to the initial design and writing phase of this draft Fire Response Plan.

\section{Introduction}

Science-based information on fire suppression, fire management, rehabilitation, and restoration of natural resources is critically needed by Federal, State, and local land-management agencies to mitigate the effects of wildland fire on people, their property, and natural resources. Most recently, Federal fire-management agencies have been requesting the USGS to provide scientific knowledge and expertise in fire-related issues. Many in these agencies recognize USGS programs and expertise in water quality, flood and landslide hazards, biological and ecological assessments, and remote sensing and mapping capabilities as authoritative in these fields and view USGS as the missing link in the interagency efforts to help manage fires and rehabilitate burned watersheds and ecosystems.

The USGS has extensive fire-science capabilities and currently supports fire-related activities within Federal, State, and local fire-management agencies. There are five interrelated and supportive components of the fire-science program within USGS: (1) risk identification-LandFire and links to traditional USGS hazard programs; (2) mitigation support for fire planning and fuels-treatment activities; (3) preparednessaiding the land-management and emergency-response agencies in preparing response actions; (4) response-supporting suppression activities; and (5) post-fire assessments and mitigation. A key element to these activities is the scientific understanding of fire ecology and support for fire-management decisions and human effects research. The components of this program address not only the immediate support needs of the wildland fire community but also support longer term research needs regarding watershed effects including the ecological and social effects from wildland fires and restoration and rehabilitation activities.

Specific activities within the USGS fire-science program include immediate wildland fire-support activities such as GeoMAC (Geospatial Multi-Agency Coordination Group), a Web-based capability to provide fire managers with wildland fire information needed during wildfire incidents. In addition, mapping capabilities within the USGS have been utilized to map fires immediately to provide a quick assessment of fire perimeters, burn severity, and wildland/urban interface zones. Further, USGS scientists have been called upon as resource advisors to provide biological, ecological, hydrological, and geological expertise locally, both during and following wildfires. Local knowledge and expertise provided by USGS scientists reflect understanding acquired through longer term scientific studies carried out by scientists. Having USGS resources available to fire-suppression staff has proved extremely useful since many suppression teams brought in are temporary and unfamiliar with local watersheds, ecosystems, and natural resources. For example, information provided by resource advisors and technical specialists has included information about hydrological conditions, geologic information, soils and soil erosion, fire effects on wildlife and plants, suppression effects on ecosystems, effects and locations of threatened and endangered species, and invasive species issues. Longer term support activities include the assessment of post-fire flooding and debris-flow hazards and effects on aquatic and terrestrial biota including threatened and endangered species. The USGS is providing research results on the recolonization of burned areas by exotic and invasive species and the effect on the flammability of a landscape. Also, USGS scientists are actively studying the interrelation between climate and wildfire and how to use this information to improve fire forecasts. This paper describes a draft Fire Response Plan for the USGS to provide technical resources in a timely manner for wildland fire support.

\section{Objective of the Plan}

The objective of this Fire Response Plan is to define the organization, coordination, and procedures to be used by the USGS to effectively support the wildland fire community and fire managers in their request for immediate and longer term knowledge and expertise that the USGS can offer. Financial support of USGS efforts on behalf of the wildland fire community will come from existing Memoranda of Understanding (MOU) and future partnerships, such as the Memorandum of Understanding for Science in Support of Fire Management that is currently being developed among the Federal land-management agencies and the USGS. In addition, the plan provides a framework for the internal coordination of existing fire-science activities within the USGS and enhanced Congressionally funded fire-science opportunities. 


\section{Organization}

This section describes existing and proposed levels of organization within the USGS fire-science program.

1. USGS Fire Science Coordination Team.-The mission of the USGS Fire Science Coordination Team is to participate in activities at the national level that pertain to the National Fire Plan and other national efforts to coordinate among Federal agencies, the Western Governors' Association, and other entities. To disseminate information within the agency, the USGS Fire Science Coordination Team consists of broad membership from within the agency including a liaison to the Director's office. Current members and the guiding document for the USGS Fire Science Coordination Team are listed in attachment A of this white paper. The Team, coordinated by Stan Coloff, has been active since 2000.

2. Regional Fire Science Coordinators.-Three new positions should be created to coordinate fire-science activities within each USGS Region. The Regional Fire Science Coordinators would be members of the USGS Fire Science Coordination Team and would work closely with Regional Directors and staff. Each Regional Coordinator would be responsible for knowing in detail the fire-science activities within the Region, would disseminate that information within the USGS and to other agencies, would jointly maintain a current Web-based USGS firescience directory with other Regional Coordinators that includes USGS members who are qualified to participate as resource personnel in wildland fire suppression and post-fire activities, particularly as BAER (Burned Area Emergency Rehabilitation) Team members. The Regional Coordinators would be directly responsible for communicating with wildland fire managers about the expertise and availability of qualified USGS personnel. In addition, the coordinators would disseminate information about fire-science research opportunities, especially interagency opportunities, to USGS scientists.

3. Post-Fire Rapid Response Teams. - In consultation with the Regional Fire Science Coordinators, the USGS Fire Science Coordination Team, the Regional Director, and PostFire Rapid Response Teams should be assembled to collect data that address critical issues of post-fire flood and erosion, including debris flows, water-quality impairment, and biologic effects, all of which may extend beyond the area burned by the fire. The Rapid Response Teams are expected to coordinate with BAER Teams but will have funding available to carry out critical post-fire monitoring to support local emergency response efforts and science objectives. Emergency funding will be available from a fund established to support USGS post-fire response activities.

4. USGS scientists carrying out fire-science research.The USGS has recognized an interdisciplinary theme of firescience research and has encouraged internal communication among USGS scientists, supervisors, and team leaders and external communication with the larger fire community. The First and Second USGS Wildland Fire Workshops are good examples of efforts to establish communication within the USGS and with the fire community. The Regional Fire Science Coordinators are expected to enhance this communication and to provide new avenues to bring this about. Scientists are encouraged to continue ongoing fire-science research and to seek outside opportunities through universities, local agencies, and other Federal agencies and through the Joint Fire Science Program.

\section{Internal Coordination}

This section diagrams the internal coordination among the organizational entities defined in the previous section.

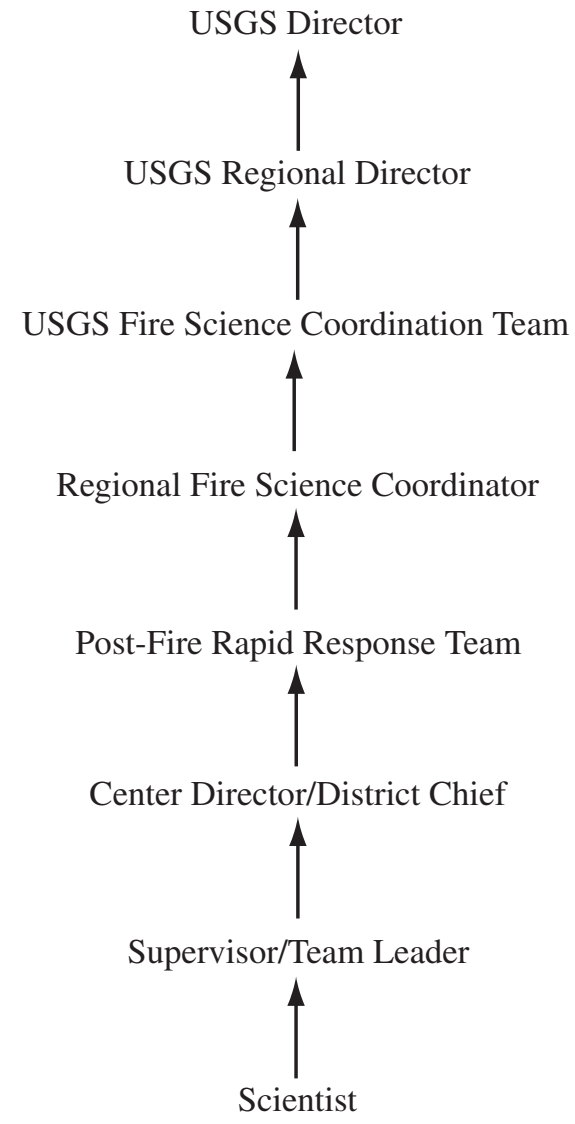

\section{Support of the Wildland Fire Community}

This section describes the roles and responsibilities of various organizational members to communicate and activate immediate and longer term responses to wildland fires.

1. Responsibilities:

A. USGS Employees

a. Accurately describe capabilities in fire-science directory.

b. Maintain fireline qualifications, necessary training, and skills required for support position in fire as necessary. Red-carded scientists must have $\mathrm{S}-130, \mathrm{~S}-190$ and $\mathrm{I}-200$ as basic courses. 
c. Acquire and maintain proper PPE (Personal Protection Equipment) as needed.

d. Make availability known to supervisor. Once approved, make availability known to local dispatch. Need to know local dispatch in each State.

e. Upon assignment, follow dispatch guidance for mobilization.

f. Keep accurate records of time using appropriate forms provided by timekeeper on the incident.

g. Maintain contact with Regional Fire Science Coordinator when possible.

h. Follow guidance and obey all incident command rules.

i. Coordinate all activities on incident with BAER Team members, or other local management and natural resource staff.

B. Regional Fire Coordinators

a. Work with Center Directors and District Chiefs, supervisors, and scientists to develop list of resources available on an annual basis.

b. Communicate with National Interagency Coordination Center (NICC) and Geographic Area Command Centers (GACCs) to convey resources available from USGS, either at annual meetings or individually arranged meetings.

c. Coordinate with BAER Team coordinators to provide any needed resources.

d. Attend meetings of other agencies to represent USGS and capabilities.

e. Help coordinate scientists in field and on an incident.

f. Keep informed of scientists' progress on incidents and provide outreach as needed.

g. Form and lead the Post-Fire Rapid Response Team.

C. Payroll/Administration Responsibilities

a. Familiarity with Fire Business Handbook.

b. Be able to interpret time sheets submitted by scientists from field.

c. Provide advice to scientists as needed with time sheets.

d. Knowledge of fire positions and incident codes (project codes).

e. One person assigned per region or coordinated nationally by Central Region.

D. Supervisors, Center Directors, District Chiefs, other Administration Responsibilities a. Recognize and support need for scientists to serve both immediate role and longer term roles in fire. Either recruit assistance or acknowledge gap in work schedule caused by scientists' commitment.

2. Activities During the Fire-Suppression Phase

Basic Flow of Communication

a. Regional Fire Science Coordinator communicates with Center Directors, District Chiefs, supervisors, and scientists to develop list of USGS resources available.

b. Regional Fire Science Coordinator communicates with National Interagency Coordination Center (NICC) and Geographic Area Command Centers (GACCs) to communicate resources available from USGS.

c. Upon approval by supervisor, scientist communicates availability to local dispatch (local dispatch communicates with NICC about availability).

d. The incident recognizes need for Technical Specialist or Resource Advisor and communicates order through NICC.

e. NICC communicates order to GACC, and GACC communicates order to local dispatch.

f. Local dispatch notifies employee of assignment.

g. Employee is dispatched to incident.

\section{Basic Flow of Communication}

The following diagram conceptually shows the basic flow of communication with regard to USGS response to major wildland fire incidents.

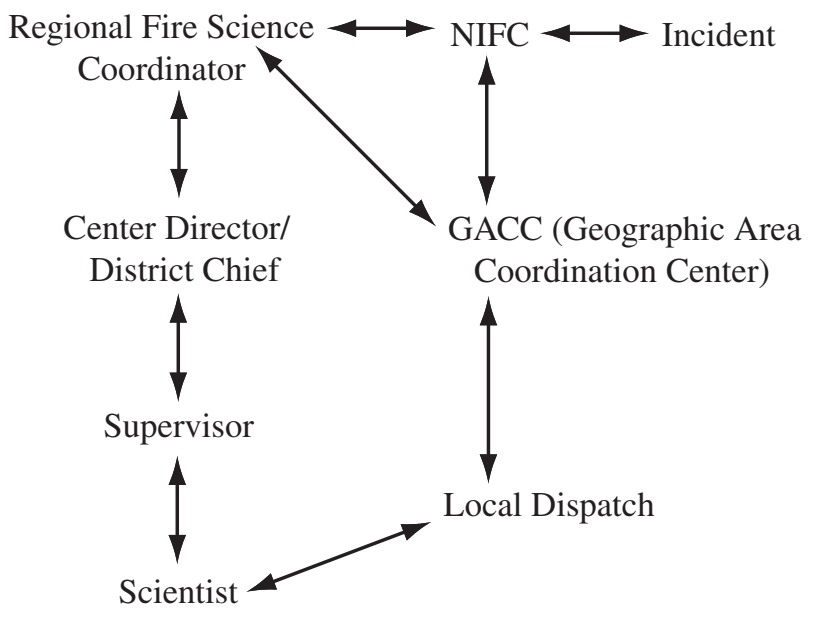




\section{Support of Ongoing USGS Fire-Science Research}

This section describes the roles and responsibilities of various organizational members to promote and carry out ongoing USGS fire-science research.

1. Responsibilities:

A. USGS Scientists

a. Continue to carry out fire-science research through customary funding sources.

b. Promote USGS fire-science capabilities.

c. Seek out and support other DOI and other Federal agency fire-science needs.

B. Regional Fire Coordinators/USGS Fire Science Coordination Team

a. Promote USGS fire-science capabilities.

b. Provide information to USGS scientists to promote interagency collaboration.

c. Seek out and support other DOI and other Federal agency fire-science needs.

d. Represent USGS at meetings.

e. Open communication channels with other research institutions.

f. Encourage partnerships.

g. Support National Fire Plan activities.

h. Seek funding for long-term studies from various sources.

i. Seek funding for new fire-science initiatives through Congress.

j. Encourage establishment of USGS Fire Science Program as a budget line item.

\section{Creation of USGS Post-Fire Rapid Response Teams}

This section describes the mechanism to assemble a USGS Post-Fire Rapid Response Team.

Assembling a USGS Post-Fire Rapid Response Team will be based on the recognition that a pressing need exists to collect data that relate to post-fire consequences such as flooding, erosion, water-quality impairment, and effects on biological resources, especially as these consequences may extend downstream from a burned area. The Regional Fire Science Coordinator, in consultation with USGS scientists and the USGS Fire Science Coordination Team, and under a directive from the Regional Director, forms and leads a PostFire Rapid Response Team. Because funds for this purpose are expected to be limited, the Response Team will exercise discretion in defining the scope of the response. The Regional Fire Science Coordinator will establish a project or task description and develop a budget in the appropriate financial software (Basis+), seek approval from the Regional Director, or designate, for expenditure of funds, and will convey an account number to the Response Team for expenditures.

The proposed membership in the Post-Fire Rapid Response Team is as follows:

- Regional Fire Science Coordinator or designate

- Ecologist (assigned by Regional Biologist)

- Social scientist (assigned by Regional Biologist)

- Geologist (assigned by Regional Geologist)

- Mapping specialist (assigned by Regional Geographer)

- Hydrologist (assigned by Regional Hydrologist)

- Water-quality specialist (assigned by Regional Hydrologist)

- District Chief, USGS-Water 


\section{Attachment A. Purpose and Objectives of the USGS Fire Science Coordination Team}

\section{USGS Fire Science Coordination Team}

Introduction.-The USGS has a wide range of capabilities and scientific expertise in wildland fire science and scientific disciplines related to fire management including: post-fire assessment and mitigation, watershed and ecosystem restoration and rehabilitation, fire ecology, fire-invasive plant interactions, GIS and mapping support for fire preparedness and suppression activities such as GeoMAC (Geospatial Multi-Agency Coordination Group), and Fire Potential Index. The expertise and experience of the individuals representing this broad range of capabilities, although relatively few in number, are well respected and recognized by the Federal fire community and academic sector as well. In addition to working with the land- and resource-management agencies directly, USGS scientists also are active in the Interagency Joint Fire Sciences Program conducting research projects as principal investigators and collaborators on an increasing number of projects competitively awarded.

The USDA Forest Service, BLM, FWS, NPS, BIA, and recently the USGS are developing plans in collaboration with the States to implement actions to address the goals set forth in the National Fire Plan Initiative. The Interior bureaus are meeting semiweekly to coordinate their activities regarding implementation planning. The USGS has been invited to participate in these meetings to help plan science and mapping support; Stan Coloff has been designated as USGS representative.

Purpose and objectives. - The primary purpose for establishing a "USGS Fire Science Coordination Team" is to provide a structure and mechanism for orderly information flow within the USGS regarding science and technical support for the National Fire Initiative. There is a lot of activity in support of this Initiative governmentwide, and in order for us to participate effectively, we need to communicate quickly the needs of the land-management agencies to appropriate entities within our organization.

The objectives of the Fire Science Coordination Team are to:

1. Distribute information regarding the planning and implementation of the National Fire Initiative to appropriate organizational units within the USGS.

2. Ensure timely, effective, and coordinated response to science and technical support requests from the Federal fire community and State and local governments.

3. Proactively communicate USGS fire-science capabilities to all levels of land-management agencies.
4. Coordinate USGS fire-science and fire-related capabilities across Disciplines and Regions.

5. Assist in the development of budget initiatives in collaboration with other Federal agencies and non-Federal interests.

Organization. - Team members represent the principal organizational units within the USGS. In addition, four technical advisors have been included. The members are responsible for (1) passing information to appropriate entities within their respective regions, directorate, and headquarters offices; and (2) facilitating coordination between and among offices.

Executive Leadership:

Stan Ponce

Tom Casadevall

Program Coordinator: Stan Coloff

Central Region:

To be determined

Western Region:

To be determined

Eastern Region:

To be determined

Associate Directorate for Biology:

To be determined

Associate Directorate for Water:

To be determined

Associate Directorate for Geography and Mapping:

To be determined

Associate Directorate for Geographic Information Office:

To be determined

Office of Communications:

To be determined

Strategic Planning and Analysis:

To be determined

Budget and Organizational Analysis:

To be determined

Technical Advisors:

To be determined

To be determined

To be determined

To be determined 